\title{
Teorias da cidade e as reformas urbanas contemporâneas
}

\section{Teories of the city and the contemporary urban reforms}

\author{
Yara VICENTINI*
}

\begin{abstract}
RESUMO
O entendimento das novas tendências do pensamento sobre a cidade representa a temática abordada. Para o período pós anos 60, discute-se como a utopia da sociedade, baseada na idéia central de progresso e apropriação social de uma tecnologia que gerasse qualidade de vida e igualdade de acesso à riqueza produzida, fragmenta-se. A concepção de vanguarda cristaliza-se, apropriada pela mídia de um mercado consumidor. Na discussão das teorias urbanas, a impossibilidade de reprodução de modelos urbanísticos universais constrói a possibilidade de abordagens mais aprofundadas sobre estas novas tendências contemporâneas, na sua relativização e diversidade. A amplitude e a diversidade das novas tendências, no âmbito do entendimento do urbanismo contemporâneo, constituiu-se em temática essencial do trabalho. Vincula-se à área de teoria do urbanismo e se propõe a desvendar formulações, conteúdos e paradigmas vinculados a estas novas tendências em análise de exemplos nacionais e internacionais de cidades.
\end{abstract}

Palavras-chave: teorias urbanas, urbanismo contemporâneo, história urbana

\begin{abstract}
The compreension of the new thought tendencies about the city represents the thematic approached. In the period pos sixties it is discussed the fragmentation on society's utopia based on the central idea of progress and social appropriation of a technology that it generates quality and equality to the produced wealth. The vanguard conception crystallizes, appropriate by the media of a consuming market.The impossibility of universal urban models reprodution, builds the possibility of approaches more deepened on these new contemporary tendencies. The width and the diversity of the new tendencies was constituted in thematic essential of the work, in the ambit about the understanding on the contemporary urbanization. This article is linked to the area of the urban theory intends to revelate formulations, contents and link paradigms of these new tendencies, analysing international and national citis examples.
\end{abstract}

Key-words: urban theories, contemporary urban, urban history

\footnotetext{
* Prof. ${ }^{a}$ Dra. do Departamento de Arquitetura e Urbanismo da UFPR e do Programa de Pós-Graduação Doutorado em Meio Ambiente e Desenvolvimento da
} PRPPG/UFPR. Pesquisadora da CNPq. 


\section{Teorias da cidade e as reformas urbanas contem- porâneas}

A reflexão histórica sobre a cidade na modernidade expõe o plano como manifestação recorrente da história do poder, distinguindo as utopias pré-modernas (as cidades morais exemplares) das topias modernas, como as define Fernández (1996), considerando, entre outros exemplos, as cidades produtivas, as reformas urbanas do século XIX ou o urbanismo socialista entre guerras.

Nestes casos, a arquitetura do tecido urbano sugere a multiplicação de um repertório, onde diferenciados projetos urbanos subordinam-se a uma lógica do plano da cidade. Portanto, a utopia da cidade moderna difunde no território mais do que um plano, um poder instituído a partir de uma complexa trama de ações de transformação territorial.

Por outro lado, as relações entre arquitetura e urbanismo, que se desenvolvem durante o movimento da modernidade, enfatizam uma vocação exemplificadora, com funções didáticas, como comenta Fernández (1996, p.7):

La arquitectura pro-urbana corbusierana (immuebles type, maisons citrohan y domino, unités d'habitacion, etc.) cumple rigurosamente esa vocación ejemplarizadora, incluso todavia, exarcebada su función regulatoria en la proposición, primeiro de los cinco puntos y luego del esquema Ciam. Varios discursos tardomodernos, aunque buscan la misma línea de determinación pro yecto/plan, por ejemplo en los planteos tecnohumanistas del Team X (Smithson, Hansen, Kahn, Van Eyck) y en sus consecuencias histórico-contextualistas (Rogers, Quaroni, De Carlo). El optimismo tecnológico sesentista (Archigram, en grupo metabolista) recae en la misma tesitura, en este caso, apelando a las megaestructuras, lisa e llanamente a un concepto de arquitectura grande.

Sobre as funções reguladoras, enquanto projeto político da modernidade, Souza Santos (1995) baseia sua análise em dois princípios, o da regulação - pautado no papel do estado moderno, do mercado e da civilização - e o da emancipação - constituído pelas lógicas das racionalidades convencionadas em uma racionalidade da moral-prática da ética, uma racionalidade cognitiva-instrumental das ciências e da técnica e uma racionalidade estética-expressiva, vinculada aos princípios de identidade.
Define, desta forma, uma complexidade interna da discussão, com a riqueza e a diversidade que articulam o projeto da modernidade, expondo um projeto ambicioso e revolucionário que, no transcorrer do século $\mathrm{XX}$, torna-se um modelo de concentração e exclusão que vai penetrar todos os princípios articulados da modernidade. Conforme o autor, no pilar da regulação o crescimento, sem precedentes do mercado, rompe os limites territoriais e institucionais, concentrando-se na formação de conglomerados que esboçam a hegemonia do final do século. No campo da emancipação, o modernismo mostra os caminhos da especialização e diferenciação funcional, no pensar da racionalidade técnica, afastando de forma irreconciliável a ciência da cultura.

Harvey (1992) também explora estes enfoques, quando enfatiza que o princípio da racionalidade estética expressa a idéia de totalidade e determina, no campo do urbanismo, sua conjugação com a possibilidade do planejamento racional, através do qual se almejava alcançar a igualdade social. Por outro lado, vai ao encontro do objetivo prático da racionalização, ou seja, a racionalização global da vida coletiva e da vida individual na cidade. Assim, a cidade zonificada veio a se constituir na culminação do projeto moderno racionalista.

Na convergência de argumentos, a crise no mundo pós-guerra configura a crise do humanismo na experiência do século XX, de crescimento do mundo técnico e de uma sociedade ocidental racionalizada onde, como aponta Vattimo (1985), a relação com a técnica e as ciências humanas, corresponde a uma ameaça, cuja reação é uma consciência mais aguda sobre as características que distinguem o mundo humano do mundo da objetividade científica, como se fosse possível ao homem despedir-se de sua subjetividade e assumir incontinente o pensamento racionalista.

É, ainda, Sousa Santos (1995) que discute como, para os anos oitenta/noventa, retrata-se a perplexidade perante a rapidez, a profundidade e a imprevisibilidade que algumas transformações recentes conferem ao tempo presente, onde a realidade parece ter tomado definitivamente a dianteira sobre a teoria. Com isso a realidade, como expõe o autor, torna-se "hiper-real" e parece teorizar-se a si mesma. A rapidez e intensidade com que tudo acontece se, por um lado, torna a realidade hiper-real, por outro lado, trivializa-a, banaliza-a. Uma realidade assim torna-se fácil de teorizar, tão fácil que a banalidade quase nos faz crer que a teoria é a própria realidade com outro nome, isto é, que a teoria se auto-realiza. 
A perplexidade retrata-se, também, na política econômica em geral e em suas práticas transnacionais, da internacionalização da economia à translocalização da população mundial, das redes interplanetárias de informação às lógicas do consumismo, da marginalização dos Estados Nacionais à perda de sua autonomia e sua capacidade de regulação. Nesta direção, o esgotamento do estruturalismo do pensamento traz a revalorização dos indivíduos que protagonizam esta mesma realidade. $\mathrm{O}$ regresso dos indivíduos - análises da vida privada, dos modos de vida, do espectador, do micro e do localismo, coloca-se, conforme considera o autor, em aparente contradição com a intensificação das interações globais, mesmo que algumas permanências, surpreendam, como o conceito de democracia, um dos importantes paradigmas sobrevivente da modernidade, cuja promoção é feita hoje pelo neoliberalismo e em dependência dele. Nestes termos, o autor comenta o moderno e o pós-moderno nos países centrais - destacando a história do capitalismo e o projeto da modernidade, polemizando:

No entanto, enquanto Habermas acredita que o projeto da modernidade é apenas um projeto incompleto, podendo ser completado com recurso aos instrumentos analíticos, políticos e culturais desenvolvidos pela modernidade (1985), eu penso que o que quer que falte concluir da modernidade não pode ser concluído em termos modernos sob pena de nos mantermos prisioneiros da mega-armadilha que a modernidade nos preparou: a transformação incessante das energias emancipatórias em energias regulatórias. Daí a necessidade de pensar em descontinuidades, em mudanças paradigmáticas e não meramente subparadigmáticas (SANTOS, 1995, p. 113).

Defende a tese de que a idéia moderna da racionalidade global da vida social e pessoal acabou por se desintegrar numa miríade de mini-racionalidades ao serviço de uma irracionalidade global e incontrolável. Nesse caso, nomeia as subjetividades correspondentes às várias formas básicas de poder que circulam na sociedade. As hierarquias que, se por um lado, se aprofundam, por outro trivializam-se e, em ambos os casos, deslegitimam-se. Os micros despotismos do cotidiano, do trabalho, do lazer e do consumo estão em parte ligados a esta perda da vontade. Se na modernidade a alienação assentava-se, sobretudo na estúpida compulsão pelo trabalho, no presente assenta- se na estúpida convulsão do consumo. Se as miniracionalidades não são racionalidades mínimas - citando novamente Habermas-, conclui o autor que perante a irracionalidade global as mini-racionalidades só poderiam ser locais em suas soluções. Introduz o conceito de plano fragmentário, como um triunfo de uma relação histórica pós-moderna, como estratégia de um poder neo-liberal, supõe o fracasso do conteúdo utopista moderno, abandonando a discussão entre teoria urbana e política, já que o novo modelo neo-liberal consolida sua natureza em processos de descontinuidade e ruptura, nos quais inclui o formalismo do tecido urbano. Sobre este aspecto é ainda Fernández (1996, p. 5) que considera:

Los términos com que se anuncia la última generación de planes - los lhamados planes estratégicos parecen, por una parte, consagrar el definitivo desinterés por la forma urbis y por outra, la volúntad de restabeler cualidades funcionales que ahora deben emerger como competitivas en los más vastos e hiperintegrados bassin territoriales.

Perante estes paradigmas, o planejamento da cidade passa agora a envolver uma operação técnica da produção de projetos de um refinado jogo capitalista, e pode-se prestar a expressar uma maior qualidade dos espaços urbanos em algum fragmento edificado, em uma abordagem da imagem competitiva de alguma cidade global. Assiste-se ao desenvolvimento de um pensamento urbano consolidado em um plano de projetos localizados, reduzindo, aparentemente, o desenho urbano a um formalismo do consumo.

Estes, sem dúvida, têm sido os extensos argumentos expostos por autores como Harvey (1992) e Frampton (1987) e exemplificados com as mais diversas celebrações de uma especulação imobiliária seletiva, como aponta Fernández (1996), a área para a Expo 98, em Lisboa, o Plano Estratégico de Barcelona, os estaleiros de Buenos Aires, as downtowns recolonizadas e gentrificadas em diferentes cidades mundiais etc. Arantes (1998) aponta para o fim do urbanismo, como já antecipava Tafuri (1985), referindo-se, mais apropriadamente, ao fim das possibilidades utópicas dos modelos do pensar a cidade moderna:

O fim do utopismo e o nascimento do realismo não são momentos mecânicos no interior do processo de forma- 
ção da ideologia do "movimento moderno". Pelo contrário, a partir do quarto decénio do século XIX, o utopismo realista e o realismo utópico sobrepõem-se e compensam-se. O declínio da utopia social determina a rendição da ideologia à política das coisas realizadas pelas leis do lucro: à ideologia arquitectónica, artística e urbana resta a utopia da forma, como projecto de recuperação da totalidade humana numa síntese ideal, como posse da desordem através da ordem (TAFURI, 1985, p. 72)

Desta forma, em um contexto de generalidades e sob um primeiro olhar, estamos todos de acordo, onde o revival do urbanismo, ou o seu fim, sucumbe às leis do mercado imobiliário nas cidades mundiais para o paradigma presente que se refere à organização dos espaços de consumo e não mais da produção. O espaço público, enquanto espaço privado, transforma-se em diversos simulacros e a simbologia do poder na cidade refere-se, agora, ao poder das grandes multinacionais e suas ramificações, um modo de vida, todos presentes nos grandes projetos urbanos nos últimos 30 anos.

Mas será que podemos nos contentar com análises gerais e recorrentes? Quando se examina o volume de investimentos urbanos nas grandes cidades mundiais ou os detalhes da infra-estrutura envolvida nestes projetos - como analisar em corte um deles, com três ou quatro lajes em pisos subterrâneos, com fantásticas inovações tecnológicas e diferentes configurações de redes de infra-estrutura sanitária, viária, ferroviária e metropolitana construídas sob a casca de uma arquitetura mundializada em grifes - examina-se, em verdade, um processo de renovação urbana, tais como as reformas urbanas nas capitais da revolução industrial do século XIX ou a reconstrução das grandes cidades européias no pós segunda guerra mundial. Para enfatizar o argumento, basta lembrar a cidade de Berlim que foi reconstruída por duas vezes nos últimos cinquenta anos.

Nessa medida, as alterações dos patamares tecnológicos do mundo industrial contemporâneo, subvertem a lógica da cidade moderna com o aumento da densidade, alterações e diversidade de usos comuns, a reinterpretação e confusão entre os espaços públicos e privados e as subjetividades de uma nostalgia individualizada, gerando amplas reformas urbanas e a inversão de paradigmas e concepções territoriais. A metrópole, tão celebrada pelo modernismo, aponta para espaços urbanos pulverizados, concentração em áreas suburbanas, redes caracterizadas não mais pelo mote da produção industrial concentrada, mas por redes tecnológicas de informação e "áreas ambientalistas" de preservação e prevenção no uso dos recursos naturais nas cidades mundiais dos países desenvolvidos.

Essas redes são, agora, transnacionais e representam significativos investimentos de renovação urbana, mesmo que possam sugerir o fim das idéias do urbanismo. Ao contrário, mesmo considerando o anacronismo de alguns mega projetos urbanos, indigestos em relação às discussões de restauração, preservação, reabilitação e imagem, seu descolamento pensado de um plano da cidade, como de um plano de sociedade caracterizam a realidade presente a ser compreendida e discutida. Portanto, não se trata do fim do urbanismo, mas sim o fim das possibilidades de reproduzir utopias sociais urbanas.

Nesse caso, Gottdiener (1993) em sua longa exposição das teorias urbanas do século XX, mapea a passagem dos modelos de análise da produção social do espaço urbano que, para além das vanguardas do início do século, caracterizaram o pensamento sobre o determinismo tecnológico a partir de teorias de equilíbrio, sistemas de cidades e previsões de infinda expansão urbana das metrópoles. Modelos estes contestados pela elaboração das teorias da economia política a partir de autores como Lefebvre (1976), Castells (1977) e Harvey (1981) entre outros, que engendraram, a partir da década de setenta, as análises de mais de uma geração de teóricos da cidade, vinculando o desenvolvimento estrutural da teoria marxista aos processos de acumulação urbana e ao Estado, em seu papel redistribuidor do capital social produzido, todos perplexos perante o contexto da produção contemporânea do espaço urbano. Gottdiener (1993, p. 272) é enfático:

Dessa maneira, a hegemonia da economia sobre os temas sociais, culturais e políticos não é uma consequência inexorável de alguma lógica estrutural do capitalismo, mas apenas a essência da ideologia burguesa. Por conseguinte, a economia política marxista e a ortodoxia dominante possuem as mesmas raízes ideológicas (...) O presente é testemunha da progressiva marginalização e confinamento espacial daqueles grupos sociais menos capazes de desempenhar um papel ativo na economia política (...) e mais importante, a ação do espaço abstrato fragmenta todos os grupos sociais, e não apenas o menos poderoso, de tal forma que a vida da comunidade local perde a rua e áreas públicas em favor da privacidade do lar. 
Em suma, redefine-se uma estratégia de atuação no espaço urbano, "neoconservadora", como afirma o autor, que propõe políticas públicas que reforcem o poder político de grupos restritos e lugares beneficiados pelo novo entendimento da desconcentração, variando em sua heterogenia da desconcentração nos subúrbios americanos em torno dos shoppings centers, ou da aplicação do darwinismo social nas denominadas áreas em depressão nas cidades latino-americanas.

Neste sentido, a análise de Arantes (1998) é superada pela própria realidade urbana, com as grandes reformas urbanas contemporâneas nas cidades mundiais, definitivamente excludentes da população urbana não mais pertencente ao corpo do mundo do trabalho ou do consumo, parte dos pressupostos de um novo urbanismo, com o desenho arbitrado da cidade-comunidade, uma cultura de animação, sem senso ou modelo plausível de uma modernidade e um humanismo recorrente. Na periferia do mundo globalizado (não mais a periferia de um capitalismo do progresso extensivo), na direção da discussão atenta de Maricato (1996), um misto de exclusão e promiscuidade dos interesses públicos e privados, com arremedos de soluções contemporâneas sem caráter.

Mesmo considerando os pressupostos perversos do novo olhar sobre a cidade, interessa examinar o pensamento teórico contemporâneo, fragmentado em múltiplas tendências, na tentativa de desvendar o político e o social do presente.

É Montaner (1993) quem expõe que, a partir de 1945 , assiste-se a uma simbiose dos pressupostos do Movimento Moderno com os aportes de outros contextos, culturas e identidades, em relação à suas tradições, suas formas específicas de entendimento do espaço, sua disponibilidade de materiais e condição criativa, mesmo que aqui se possa estabelecer uma ressalva em relação a posições críticas mais veementes e específicas, como a expressa por Jacob (1964). Por um lado, tratava-se, no entender otimista deste autor, de superar o esquematismo da produção do Movimento Moderno e resgatar a ruptura com a tradição e a evolução histórica da arquitetura e do urbanismo. Por outro, aceitava-se a recolocação da idéia de cidade, ante o que considera o indiscutível fracasso da urbanística racionalista, com sua separação de funções e o entendimento da criaçãoไrenovação de cidades a partir da aplicação de princípios cartesianos.

Com estes argumentos, expõe na análise do pensamento contemporâneo, uma organização metodológica/ temática que inclui: a arquitetura e sua relação antropológica; a visão da arquitetura da cidade ou, como denomina, a racionalidade da disciplina arquitetônica; a arquitetura e urbanismo como sistema comunicativo; a arquitetura e urbanismo como conceito na busca de uma nova retórica da abstração formal; a arquitetura e a exclusão do pensamento do urbanismo na alternativa tecnológica; e a linha de argumentação da arquitetura e urbanismo em relação ao contextualismo cultural.

De maneira correlata, o autor Frampton (1987) vai formular sua análise a partir do conhecimento do período do pós-guerra, utilizando-se de categorias de análise que buscam, na história do pensamento político e social vinculado à modernidade no século XX, um elo contemporâneo onde, em forma similar a Montaner (1993), esquematicamente aponta para a compreensão das tendências contemporâneas do pensamento sobre a arquitetura e o urbanístico: as idealizações racionalistas, baseadas no formalismo do objeto; a relativização dos conceitos de tempo e espaço na superação de uma datação de estilos e desenhos da forma urbana; a busca da contextualização populista na cidade; o apelo ao estruturalismo, aqui entendido como as propostas e formulações antropológicas e étnicas ou, ainda, o regionalismo crítico, como tendência de reconstrução da memória cultural e sua reinterpretação, derivação do próprio entendimento contextualista no urbanismo contemporâneo. A discussão sugere diferentes temáticas para aprofundamento, como: cidade e racionalismo pragmático; cidade, etnia, segregação e violência; cidade e subjetividade; cidade e forma urbana; memória, permanências e releituras; etc.

Em outra direção, Castells e Borja (1996) apresentam argumentos em que são expostos os parâmetros do denominado Plano Estratégico, onde as cidades são analisadas como atores políticos e sociais complexos, como cidades no interior do processo de globalização, elas mesmas atuando no sentido de promoção de acordos e associações, como núcleo central de articulação entre a sociedade civil, a iniciativa privada e as instâncias do Estado. A propagação destes pressupostos, o "Projeto Cidade", vem ganhando expressão significativa em várias cidades européias. Incluem as discussões de espacialidade e subjetividade com debates pertinentes às cidades mundiais e cidades latino-americanas. A ênfase na discussão coloca-se na diversidade do mundo contemporâneo ao abordar a consciência individualista e sua manifesta "forma de solidão", vinculada aos não-lugares e à conquista do anonimato. Nes- 
ses termos, o universo dos espaços padronizados os torna intercambiáveis, equivalentes, gerando, supostamente uma paralisia da subjetividade que se reflete na impossibilidade do pensamento utópico.

Os exemplos que apontam para esta discussão são inúmeros e tratam da implantação de reformas urbanas contemporâneas. A seguir, destacam-se exemplos representativos para os argumentos deste artigo.

\section{As reformas urbanas contemporâneas}

Talvez a política de renovação urbana da cidade de Berlim seja uma das mais significativas em curso nas cidades européias, até pelo caráter simbólico de recuperação de uma cidade dividida no pós-guerra pelo muro de Berlim e pelo fato de vir a se transformar na nova capital da Alemanha, após quase meio século de divisão do país.

Ao pensar a cidade de Berlim, surpreende como uma cidade pode ser reconstruída duas vezes em cinquenta anos, primeiro como cópia fiel da cidade destruída pela segunda guerra, como mostram as fotos da época e, neste momento, como símbolo de uma vontade de inaugurar um novo período histórico na tentativa de esquecimento do passado recente.

Antes mesmo da queda do Muro na década de 80 e sob o tema - o centro da cidade como lugar para viver desenvolve-se a experiência conhecida do IBA - Internationale Bauausstellung - dividida em áreas de recuperação e áreas para novas construções. Para o processo de recuperação definiram-se zonas próximas ao muro que dividia a cidade, onde foram organizados concursos para as áreas de renovação urbana, abarcando conjuntamente as áreas urbanas de Tegel, Prazer Platz, Distrito de Tiergarten de Friedrichstadt Sul na cidade de Berlim. Participaram desta experiência diferentes arquitetos, como os italianos Aldo Rossi, Giorgio Grassi e Vittorio Gregotti, além de outros como Charles Moore, Oswald M. Ungers, Hans Kollhoff e Peter Eisenman. Para Colquhoun (1989) as intervenções do IBA representaram a retomada do conceito de espaço urbano de domínio público na Alemanha.

O modelo de reconstrução, conforme afirma Bronstein (1996), procurou restituir a estrutura policêntrica da cidade e o traçado urbano tradicional, com seus padrões de ruas, fachadas, quarteirões e espaços públicos. Nos quarteirões caracteriza-se seu fechamento, conformando os pátios internos, negando a ausência de hierarquia das expan- sões modernas do pós-guerra e a adoção do zoning de configuração de espaços abstratos. Pretendeu-se a distinção entre espaços públicos, semi-públicos e privados, em uma referência ao texto de Aldo Rossi - Arquitetura da Cidade - publicado pela primeira vez em 1965 , que preconizava a leitura urbana através da arquitetura e dos monumentos na cidade. Também a participação em projetos de Carlos Aymonino e Robert Krier denotam a assimilação da tendência italiana no pensamento do reconstruir a cidade, além da abertura a debates e conferências com os convidados Robert Venturi, Oswald Ungers e Charles Moore. Na avaliação de todo o processo, em 1987, constatou-se que as áreas de renovação urbana mostraram-se mais econômicas e garantiram a permanência de quase a totalidade da população, inclusive as famílias de origem turcas, nos seus locais de habitação.

Por outro lado, as críticas formuladas no período dizem respeito à diversidade deste processo que conduziu em alguns trechos urbanos a uma dispersão e fragmentação, como afirma Lampugnani (1990). Em verdade o tema abordado por este autor - a cidade da tolerância - coloca a nú uma vontade política de abertura na cidade alemã de Berlim, um mostruário internacional que introduz o pensar “estrangeiro", uma característica também perceptível nos projetos urbanos contemporâneos da década de noventa.

No entanto, ao final da década de 80 e na década de noventa inaugura-se para Berlim um novo patamar sobre o pensar a cidade, abandonando uma política de renovação com participação social e intervenções localizadas em pequenas escalas, capazes de propagar uma vontade política de união e "reconstrução da cidade."

Em controvérsia, adota-se uma política empresarial de renovação urbana, alinhada a um contexto político "conservador-moderno" que consegue distinguir-se das atabalhoadas intervenções privatizantes do espaço público em Londres (Doklands com o governo conservador de Thather, na década de oitenta) ou das simbólicas reinvenções do espaço público em Paris, nas intervenções de Miterrant. Experiências "passadas", difíceis de manter hoje como exemplos paradigmáticos, como se pensava, em um período de rápidas superações.

Ao final da década de oitenta, o poder local berlinense declara 39 zonas de intervenção e investigação, com o objetivo de reabilitar 180.000 habitações que ocupam 1.500 ha urbanos, incluindo amplas áreas de expansão. Destas, aproximadamente 147.000 são anteriores ao ano de 1918, não atingidas pela destruição da 2. ${ }^{\text {a }}$ guerra mundial, e 65.000 


\section{IMAGENS 1 - BERLIM}

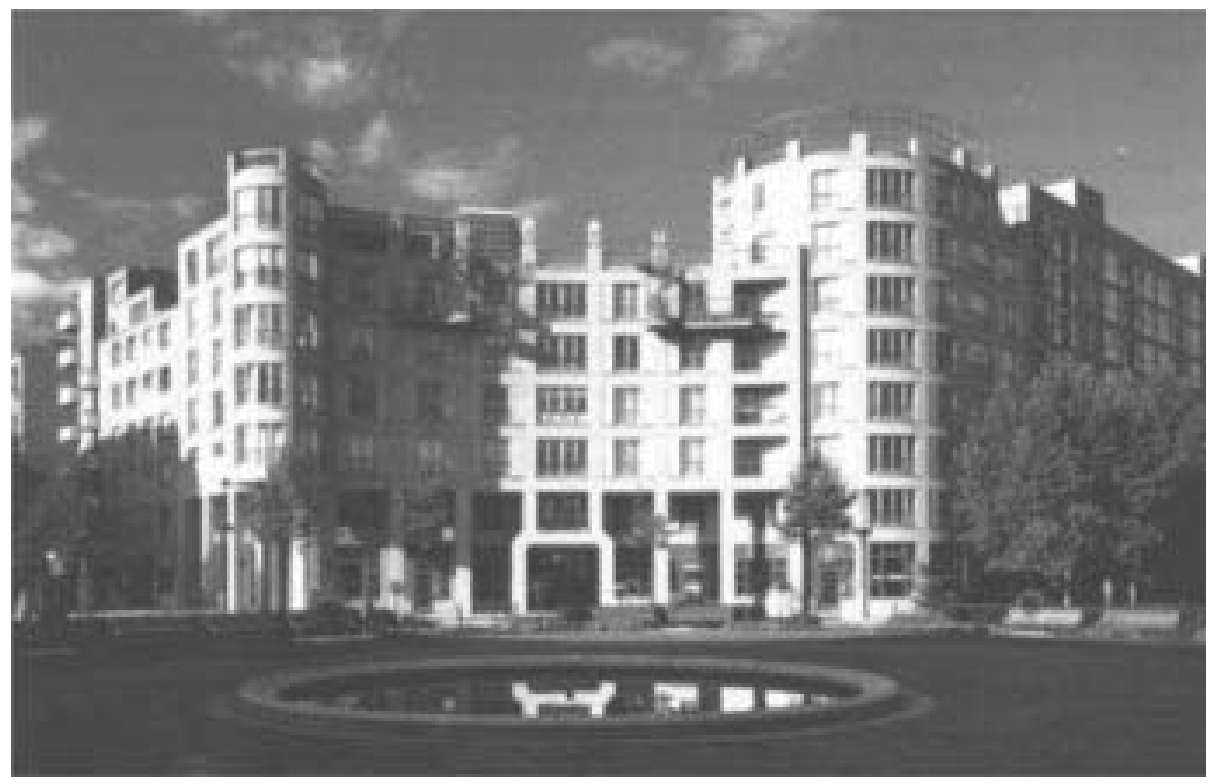

1. RENOVAÇÃO URBANA IBA

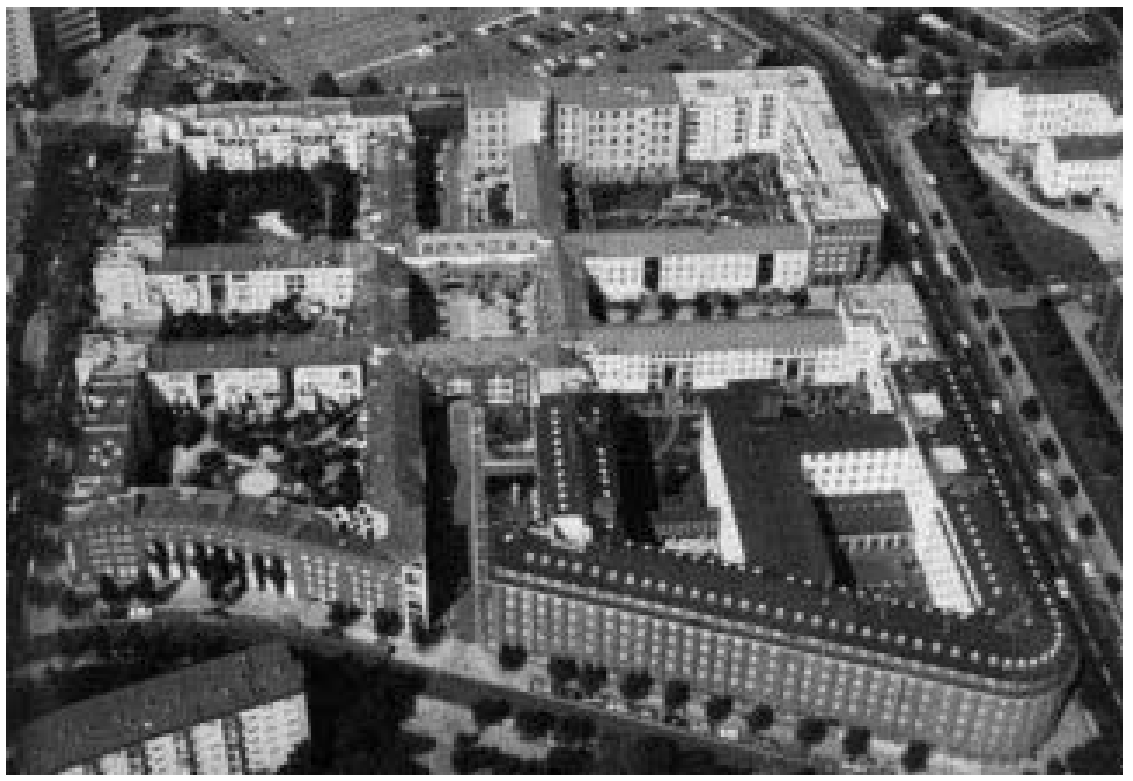

2. RENOVAÇÃO URBANA IBA

FONTE: INTERNATIONALE BAUAUSSTELLUNG BERLIM - IBA. Project Report, Sena to for Building and Housing. Berlim: [s.n.], 1990; Diepgen, E. (Org.). The Catalogu and Editorial. Berlim: Status, 1998. 
IMAGENS 1 - BERLIM

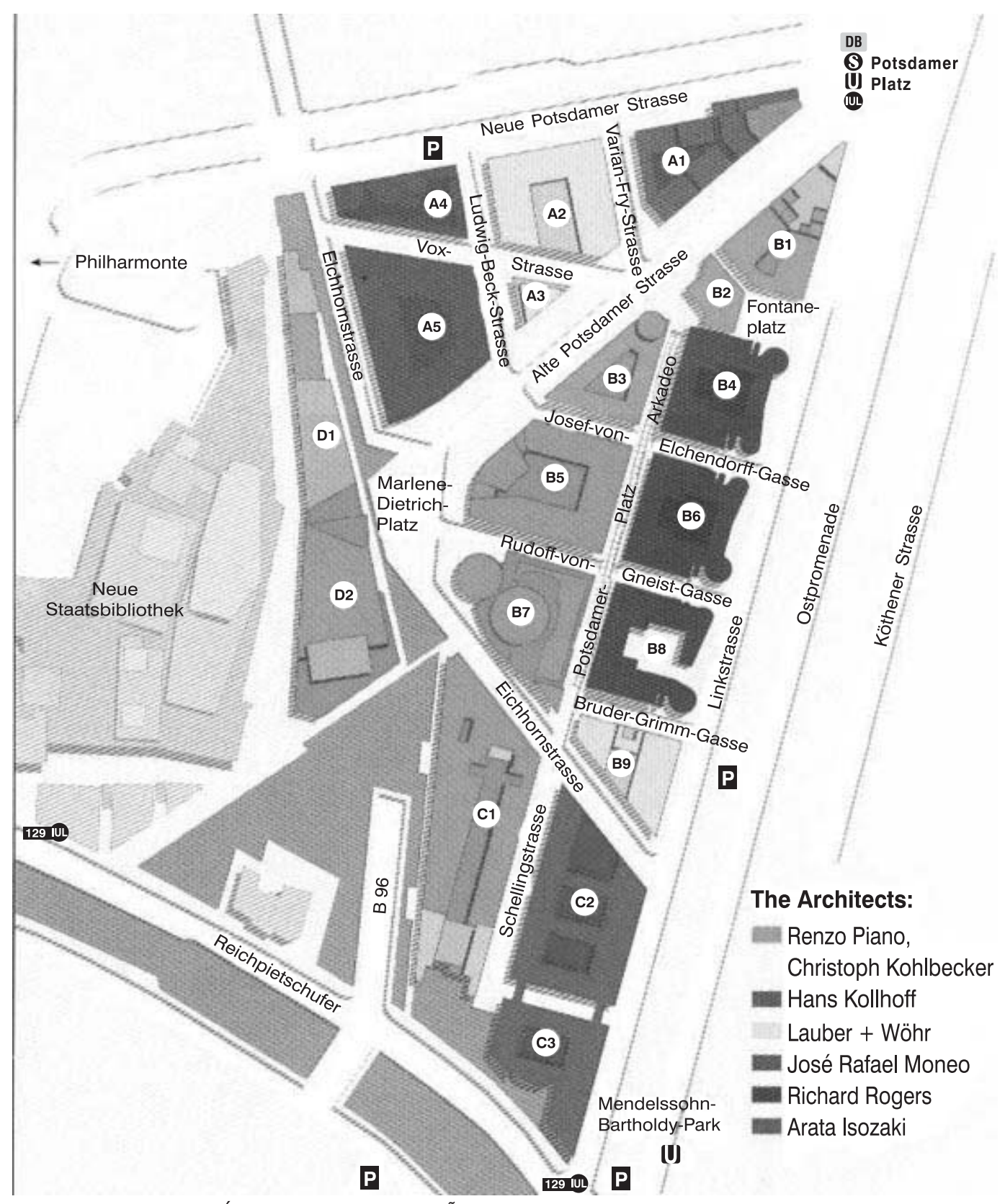

3. ÁREA DE INTERVENÇÃO CENTRAL - POSTDAMER PLATZ

FONTE: INTERNATIONALE BAUAUSSTELLUNG BERLIM - IBA. Project Report, Sena to for Building and Housing. Berlim: [s.n.], 1990; Diepgen, E. (Org.). The Catalogu and Editorial. Berlim: Status, 1998. 


\section{IMAGENS 1 - BERLIM}

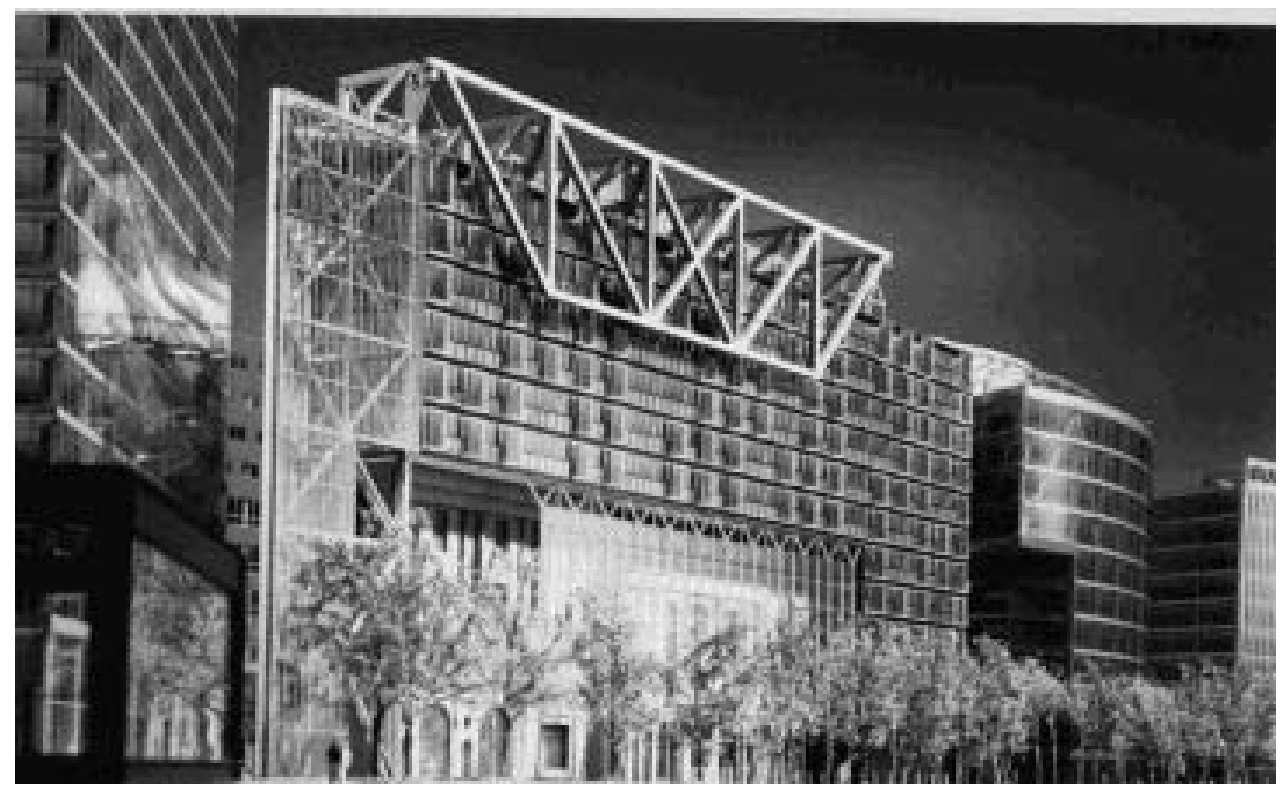

4. POTSDAMER PLATZ - SONY CENTER

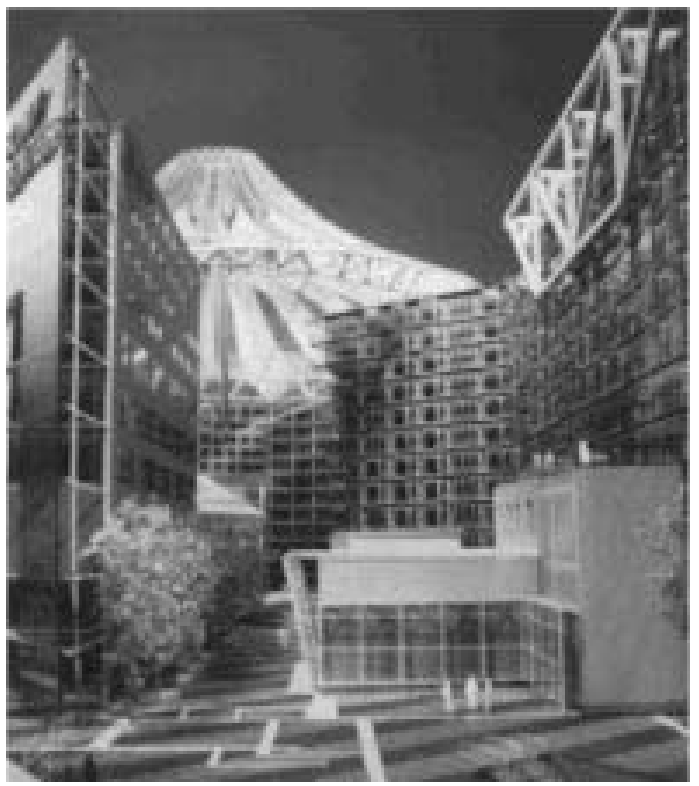

5. POTSDAMER PLATZ - SONY CENTER

FONTE: INTERNATIONALE BAUAUSSTELLUNG BERLIM - IBA. Project Report, Sena to for Building and Housing. Berlim: [s.n.], 1990; Diepgen, E. (Org.). The Catalogu and Editorial. Berlim: Status, 1998. 


\section{IMAGENS 1 - BERLIM}

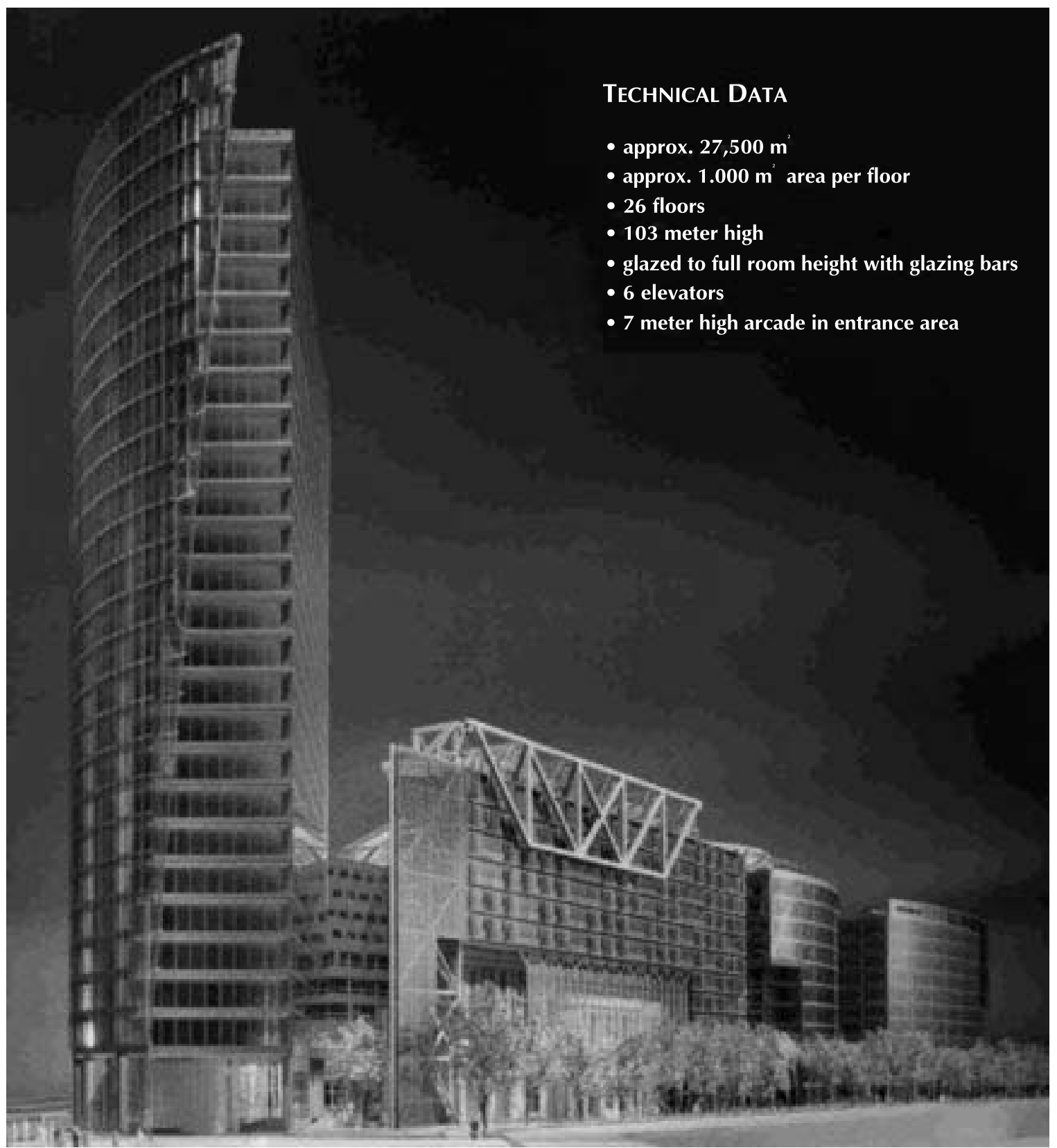

6. POTSDAMER PLATZ - SONY CENTER

FONTE: INTERNATIONALE BAUAUSSTELLUNG BERLIM - IBA. Project Report, Sena to for Building and Housing. Berlim: [s. n.], 1990; Diepgen, E. (Org.). The Catalogu and Editorial. Berlim: Status, 1998. 
não possuíam banheiros internos, conforme relata Cladera (1995). Os investimentos são públicos e dão continuidade à recuperação da cidade, acrescentando-se, agora, a idéia de transferência da capital e de consolidar uma imagem pública universal de uma cidade aberta. A reconstrução da Postdmer Platz, área retratada no filme Asas do Desejo como um imenso vazio urbano central, resultante da derrubada do muro, em frente à arquitetura premiada do museu de arte moderna, perpetua este significado simbólico de abertura, com projetos mundiais. Mesmo o projeto do novo parlamento, de arquitetura internacional, reforça este argumento e causa estranheza na população. Qual a nação que tem seu parlamento projetado por um estrangeiro?

No entanto, para não concluir apressadamente sobre uma arquitetura do simulacro ou da reprodução de espaços pós-modernos na cidade, tão diferentes da experiência do IBA, é preciso atentar para a infra-estrutura (aquilo que não aparece e está enterrado) que os projetos contemporâneos de Berlim envolvem (ver imagens 1).

O paradigma é regional/nacional de recorte ambiental. A cidade mundial, como se deseja, não é uma reprodução fortuita e imagética do contemporâneo, mas se insere em uma rede de cidades convencionadas pela questão ambiental, pautadas na configuração espacial de bacias hidrográficas, que substituem, definitivamente, os recortes de redes de cidades como paradigma da década de setenta.

Sob a Potsdamer Platz esconde-se uma extensa área de recuperação ambiental dos recursos hídricos (uma espécie de piscinão - reservatório) intercalado pelos acessos ferroviários internacionais, metroviários regionais além das pistas rodoviárias subterrâneas e estacionamentos. $\mathrm{O}$ custo da obra estimado em torno de U\$ 9 bilhões (comparativamente duas hidrelétricas brasileiras ou uma e meia guerra de Kosovo) não deixa dúvidas em relação à profunda reforma urbana em infra-estrutura, que extrapola os argumentos e as críticas de uma reprodução imagética da cidade. Neste caso, não se trata de reproduzir uma simbologia universal das cidades mundiais contemporâneas, mas de adaptar em um novo patamar tecnológico a cidade pós-moderna, mesmo que a arquitetura visível seja "estrangeira, estranha" e configure espaços privados de aparência pública, cercados de ícones das empresas multinacionais, assim como, uma década antes, o entorno do Arc'de La Defense, em Paris.

Em forma paralela, o processo de reabilitação urbana de Lisboa, ao longo das duas últimas décadas, vem se caracterizando pelo estímulo à preservação do patrimônio histórico-cultural, com prioridade às condições de habita- ção e de preservação da identidade do bairro e trabalhando através de uma gestão pluridisciplinar. No período pósRevolução dos Cravos, a discussão sobre reabilitação urbana, assim como sobre os novos projetos urbanos, destacou-se em âmbito internacional, com projetos publicados em revistas especializadas e diferentes livros de autores críticos e professores das Universidades de Lisboa, Coimbra e do Porto, como Garcia Lamas (1993) e Portas (1985).

A seguir, na década de noventa, com o ingresso de Portugal na comunidade européia, as intervenções urbanas contemporâneas em Lisboa caracterizaram-se por uma renovação de infra-estrutura e pela elaboração de Planos Estratégicos para a cidade e região, com forte viés ambiental. Entre as intervenções significativas deve-se citar a reconstrução do Chiado - bairro histórico central - depois do grande incêndio de 1988, a nova ponte sobre o Rio Tejo ( com $14 \mathrm{Km}$ de extensão), um importante conjunto de equipamentos sociais e culturais, a ampliação e remodelação da rede de Metrô, a criação de novas áreas verdes, a remodelação da frente ribeirinha, e a área de reconversão urbana na zona oriental da cidade - a Expo 98 - em alusão à temática dos oceanos, com novos projetos reconhecidos mundialmente. Projetos que evocam planos de intervenção pontuais de grande magnitude e impacto sobre a imagem urbana. No caso de Lisboa, cria-se uma imagem de "cidade mundial" que, na prática, constitui-se em projetos urbanos afeitos à consolidação de zonas especiais e de abertura ao mercado de novas áreas urbanas equipadas.

Importante frisar que, a elaboração de planos estratégicos para as cidades européias é consequência direta de exigência da comunidade européia para empréstimos aos governos locais. Tem sido assimilada por diferentes contextos urbanos, em uma difusão de um novo modelo de planejar e atuar nas cidades. Não se trata de um modelo de intervenção hegemônico, mas de um modelo de descentralização da gestão acrescido de políticas públicas sociais, ambientais e urbanas.

Portas (1985), alinhado ao pensamento de Borja (1996), entende que o projeto urbano aparece como uma alternativa ao sistema de planos diretores, como uma nova estratégia de formulação de políticas urbanas com instrumentos autônomos da administração, por um lado, e como processo de desenvolvimento da cidade, por outro lado, revertendo o sistema de planos diretores, agora considerado convencional e ultrapassado.

Ao novo modo de administrar a cidade, seja na cidade de Lisboa ou em cidades européias consideradas mun- 


\section{IMAGENS 2 - LISBOA}

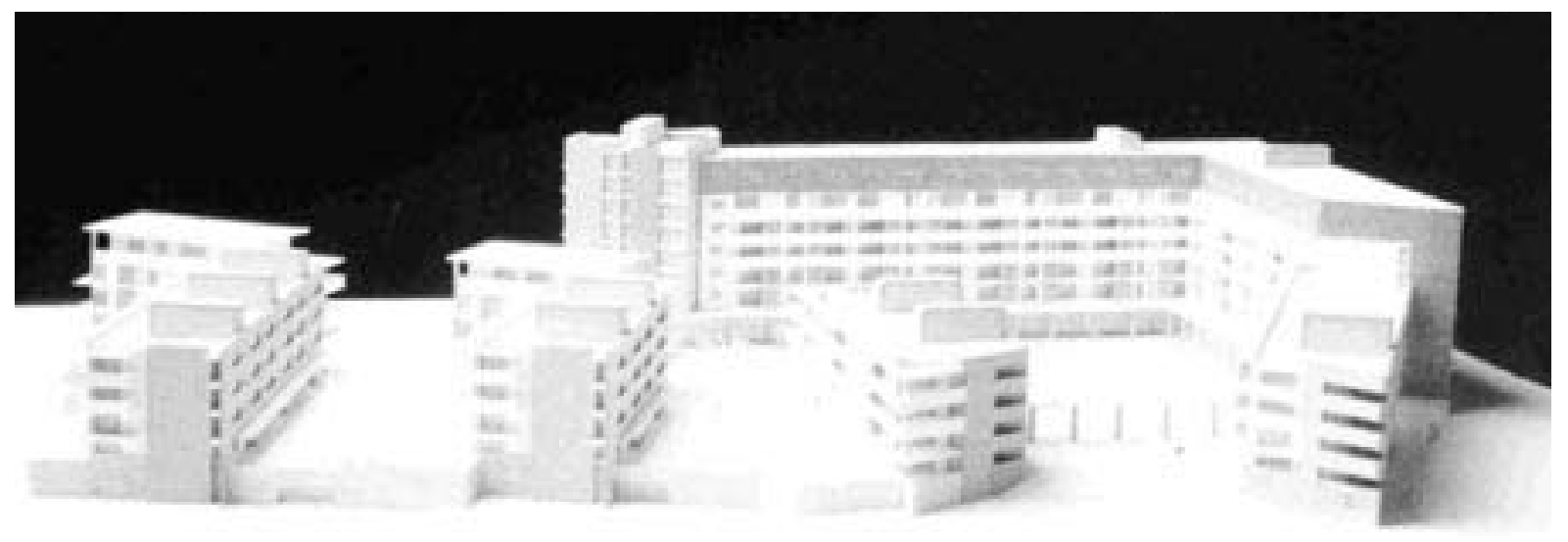

1. VILA EXPO 98

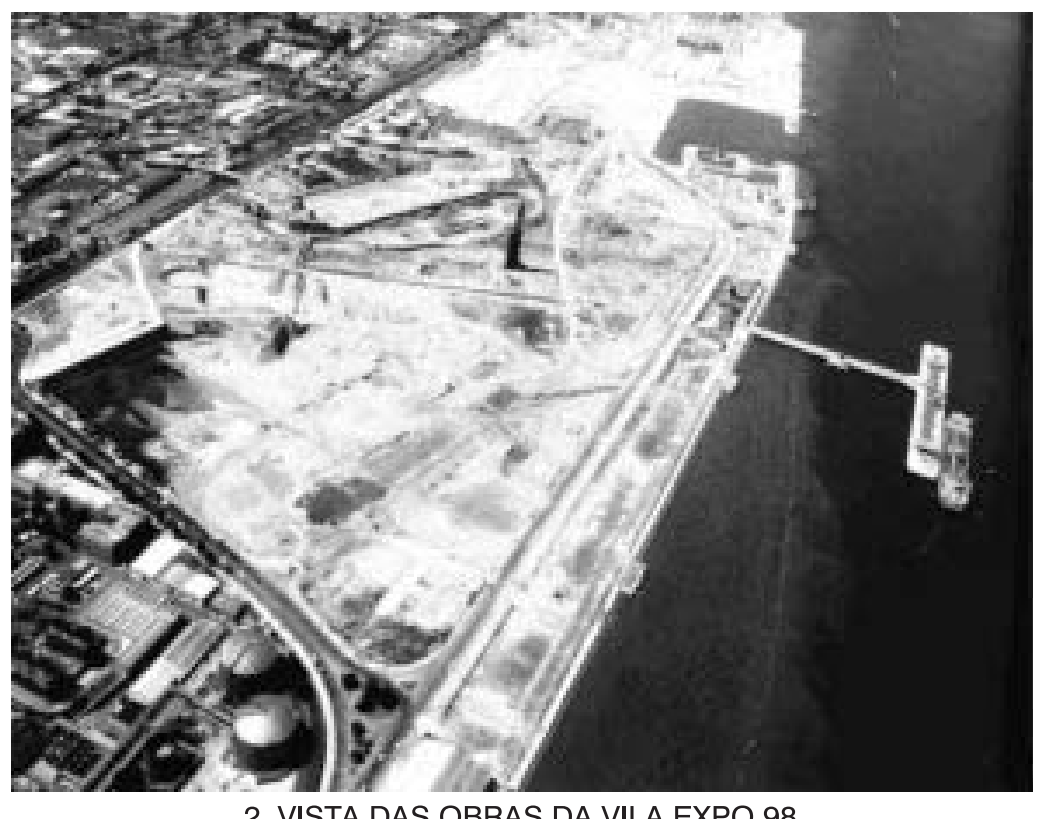

2. VISTA DAS OBRAS DA VILA EXPO 98

FONTE: FRANÇA, J . A. Lisboa: Urbanismo e arquitetura. Lisboa: Horizonte, 1997. 


\section{IMAGENS 2 - LISBOA}

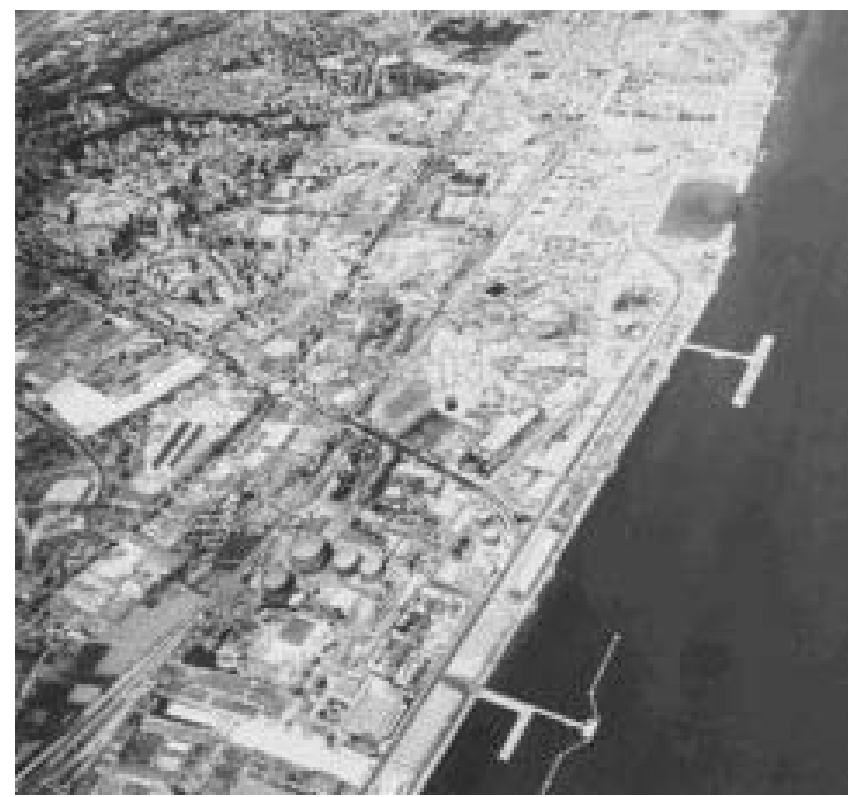

3. VISTA ANTES DAS OBRAS DA VILA EXPO 98

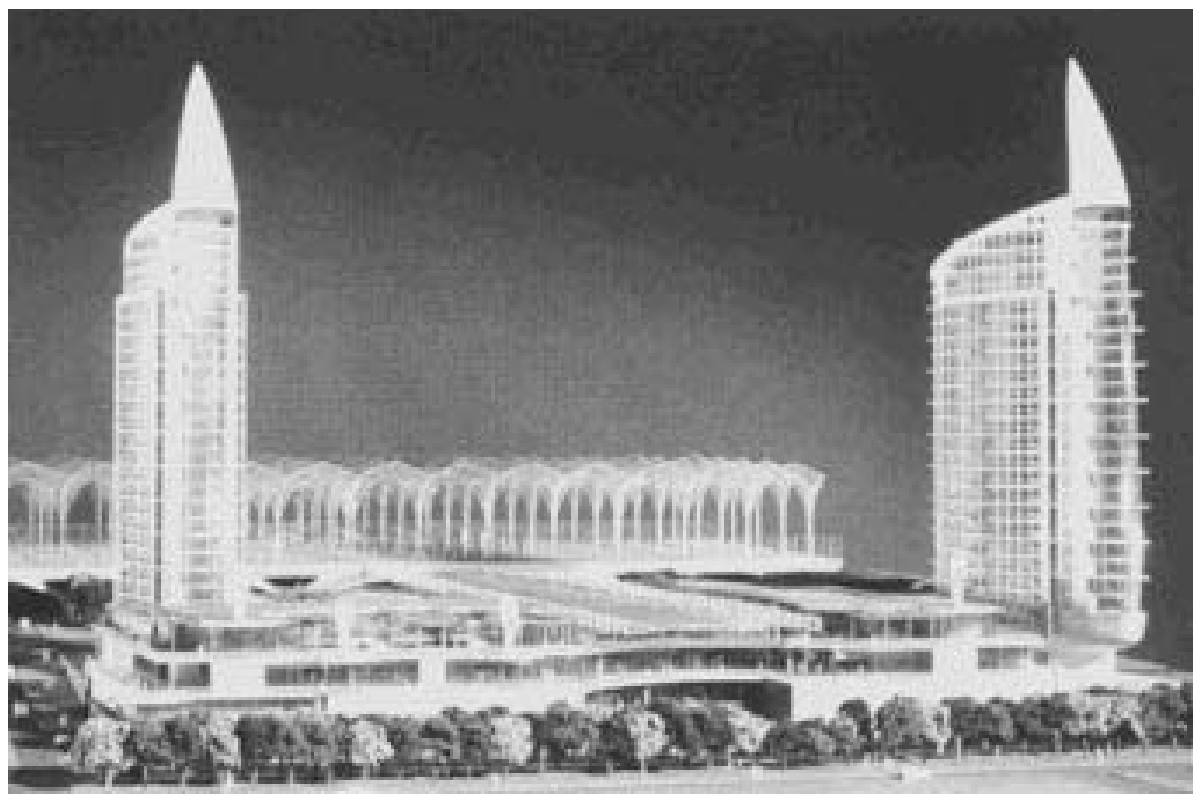

4. SHOPPING

FONTE: FRANÇA, J . A. Lisboa: Urbanismo e arquitetura. Lisboa: Horizonte, 1997. 
diais, acrescenta-se a configuração de um novo paradigma regional, o ambiental (por isso as exigências de EIAS e Rimas da CEE) que substitui o metropolitano de redes de cidades, por uma abordagem de redes transnacionais de infra-estrutura com enfoque ambiental. O paradigma ambiental reverte-se em temática e meta de desenvolvimento urbano.

Em Lisboa, em 1990, o ainda denominado Plano Diretor foi concebido com relação às novas idéias de um processo de intervenções pontuais. Em 1992, rebatizado de Plano Estratégico, como exigência da CEE, inclui as questões regionais ambientais, onde em relação à nova travessia do Rio Tejo, a Ponte Vasco da Gama, junto às docas dos Olivais onde se define a nova área para a implantação da Expo 98. Portanto, mais do que uma nova porção para a expansão da cidade, a Expo 98 significou extensivos investimentos de saneamento, implantação de coletores e estação de tratamento dos poluentes domésticos e industriais, criando áreas de lazer com percursos de barcos, a pé, de bicicleta. A Expo 98 constituiu-se, portanto, em parte deste mega projeto de recuperação ambiental, definindo espaços de especulação imobiliária em todo seu entorno, já com as torres de escritórios e residenciais em franca expansão. E pode ser considerada uma vitrine correspondente à vontade de inserção do país nos novos patamares de infra-estrutura das cidades mundiais européias.

A visão equivale a um mergulho em um espaço urbano "pós-moderno", simbólico e mediático que ocupa 330 hectares da denominada zona de intervenção. Pode-se embarcar em um teleférico que sobrevoa as margens do rio Tejo ou subir na Ponte Vasco da Gama, com 120 metros de altura. Junto ao mega projeto foi construída a Estação do Oriente, nova intersecção dos trens internacionais e do metrô urbano, projeto de "grife" do engenheiro espanhol Santiago Calatrava. O Pavilhão de Portugal, projetado pelo arquiteto Álvaro Siza Vieira, também responsável pelas reconstruções do bairro histórico do Chiado, revive as conquistas marítimas lusitanas dos séculos XV e XVI; o dos Mares exibe a evolução da relação do homem com os oceanos; e o mais paradigmático, que se constitui no Pavilhão dos Oceanos, concebido pelo americano Peter Chermayeff (ver imagens 2).

Nos investimentos, além dos empréstimos da CEE, concorreram diferentes empresas multinacionais, como Coca-cola, Telecom, Siemens, Shell, Tap, Xerox, Sony, CTT, Alcatel e Microsoft, entre outras. As mesmas empresas multinacionais que concorrem há três décadas com as gran- des reformas urbanas contemporâneas das cidades mundiais, no novo contexto do processo de produção como o define Castells (1995), entre outros autores.

Do ponto de vista teórico e conceitual em relação ao pensamento urbanístico, não se pode falar em fim do pensamento urbano, mas sim, em fim do pensamento urbano moderno, como já apontava há duas décadas Tafuri (1985), ou mesmo das utopias pensadas que o mesmo engendrou. O novo espaço urbano equipado corresponde a diferentes simulacros sociais, políticos e culturais, que o mundo do consumo urbano assimila e converte em imagens diversificadas, por vezes melancólicas de um novo pensar sem utopia, sem os caros conceitos de progresso e desenvolvimento, sem porvir nos moldes humanitários do século XIX.

O novo senso do espaço urbano, mantidos os cada vez mais sofisticados processos de exclusão e de exploração imobiliária, como já constataram Arantes (1998) e Harvey (1992), transforma em espaço “público” os espaços privatizados de uma alegoria urbana do consumo. A arquitetura de eventos das cidades mundializadas revertese em espetáculos do não-lugar, como caminhar por calçadas na Expo 98 que em determinados pontos explodem em tufos de água colorida (verde, azul ou vermelho), como se o espetáculo da humanidade se resumisse a produzir surpresas tão fugazes.

Em verdade, as profundas transformações sociais condicionaram uma fase; conforme Busquet (1976), caracterizada por um movimento de reconversão das condições de projeto, que adquire uma capacidade reestruturante sobre a cidade em seu conjunto, como a transformação de espaços intersticiais que caíram vazios de atividades, ou de reabilitação de áreas abandonadas. Neste sentido, o plano estratégico como mote da CEE interessa às cidades mundiais européias, transformando-se, em tentativas de reinterpretação e assimilação, em caricaturas na América, contrastando com as áreas urbanas de extrema pobreza a partir do agravamento das desigualdades sociais e dos problemas ambientais.

Deste lado da moeda encontram-se as reformas urbanas contemporâneas nas cidades brasileiras, mesmo que os paradigmas assimilados sejam concorrentes, basta uma rápida análise, de alguns exemplos escolhidos, para o destaque das diferenças que se colocam de forma conceitual e projetual.

À cidade de Salvador associam-se os termos memória e identidade, que apesar de empregados na atualidade 


\section{IMAGENS 3 - CURITIBA}

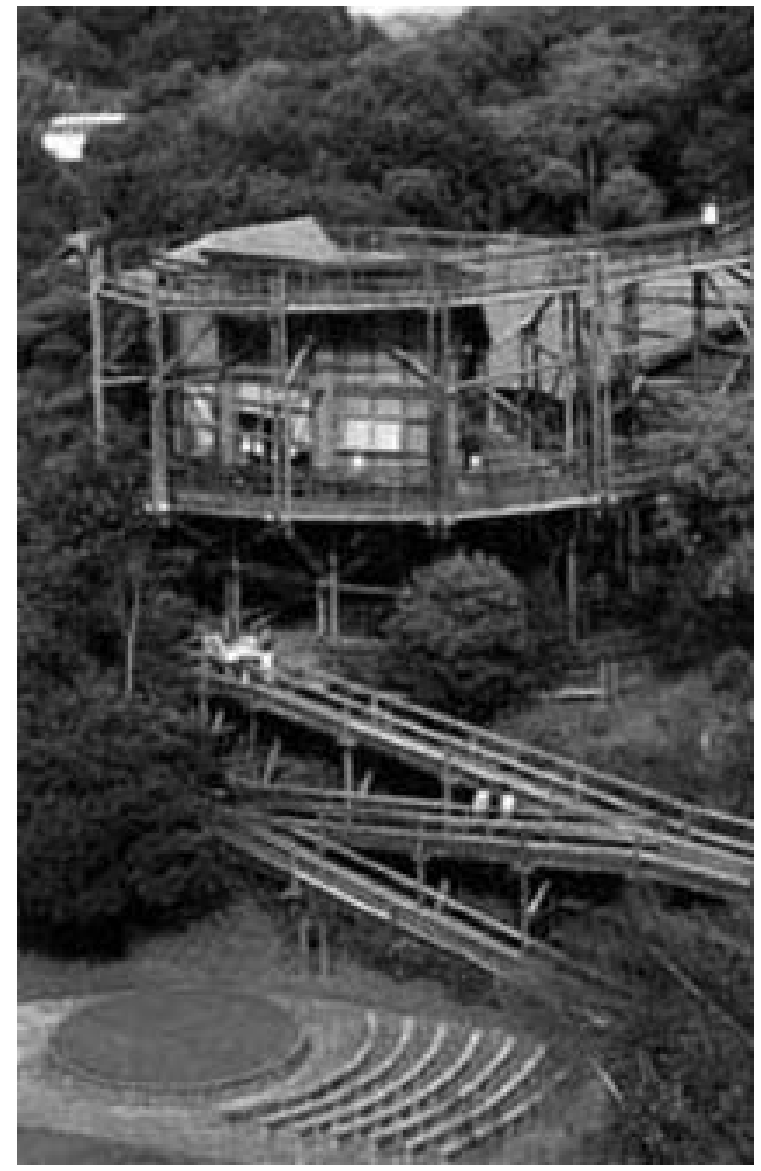

1. UNIVERSIDADE LIVRE DO MEIO AMBIENTE

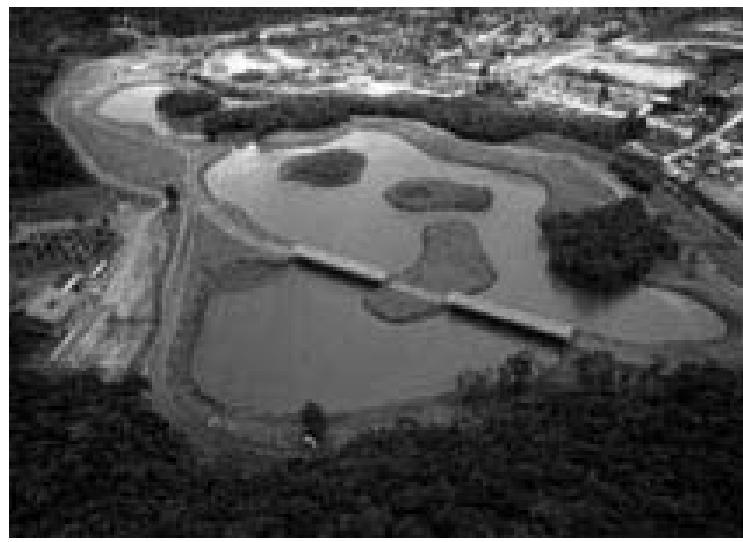

2. PARQUE TINGUI

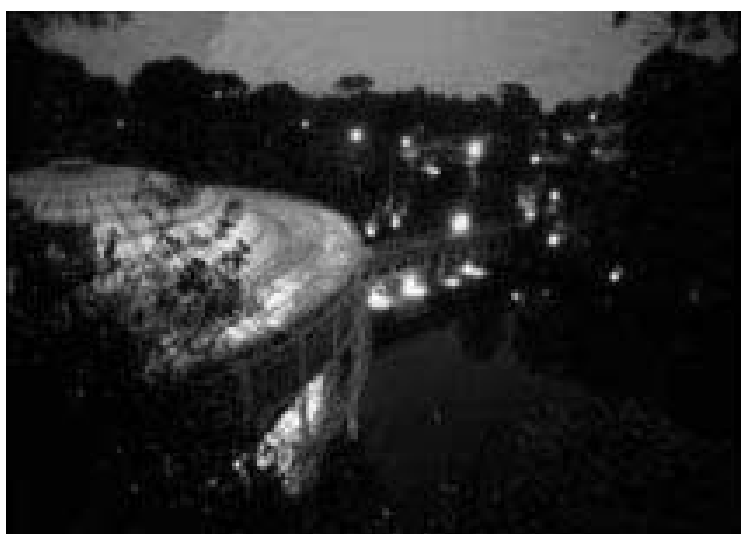

3. ÓPERA DE ARAME

FONTE: PREFEITURA MUNICIPAL DE CURITIBA. Site de Curitiba. <www.curitiba.pr.gov.br> acesso em: 2000. 


\section{IMAGENS 3 - CURITIBA}

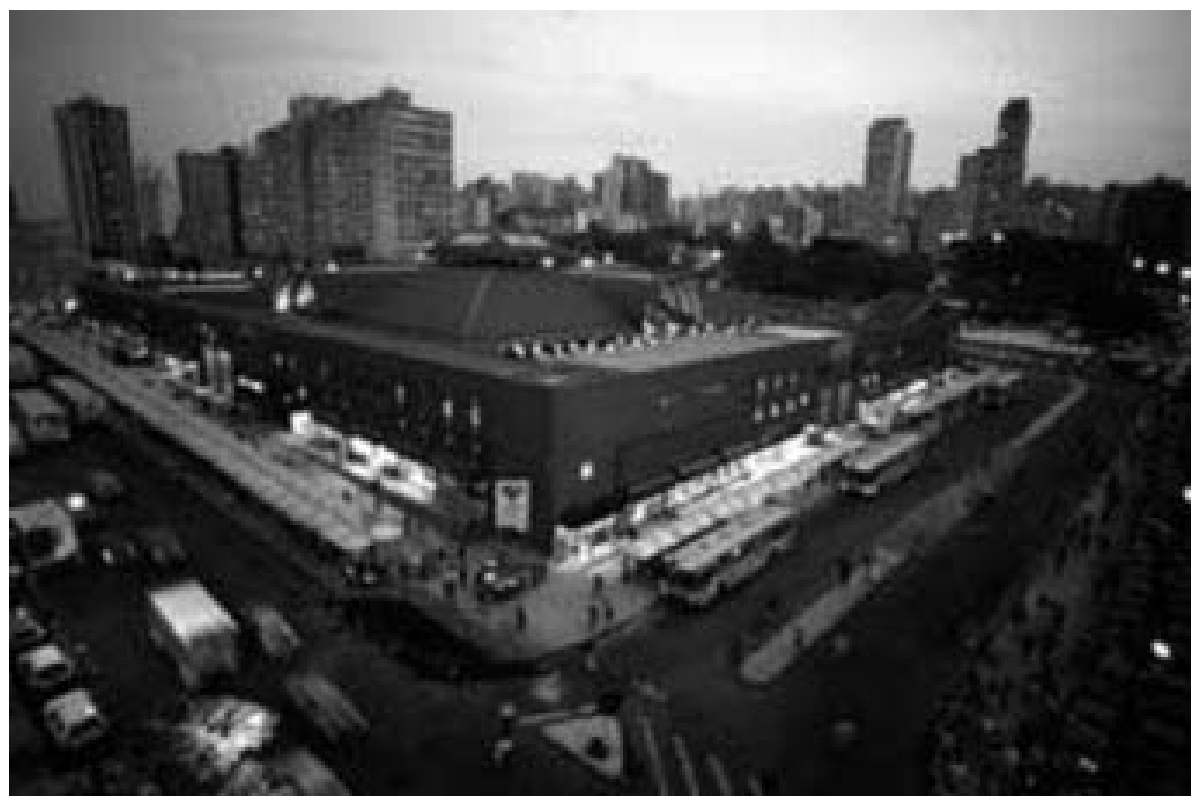

4. RUA DA CIDADANIA

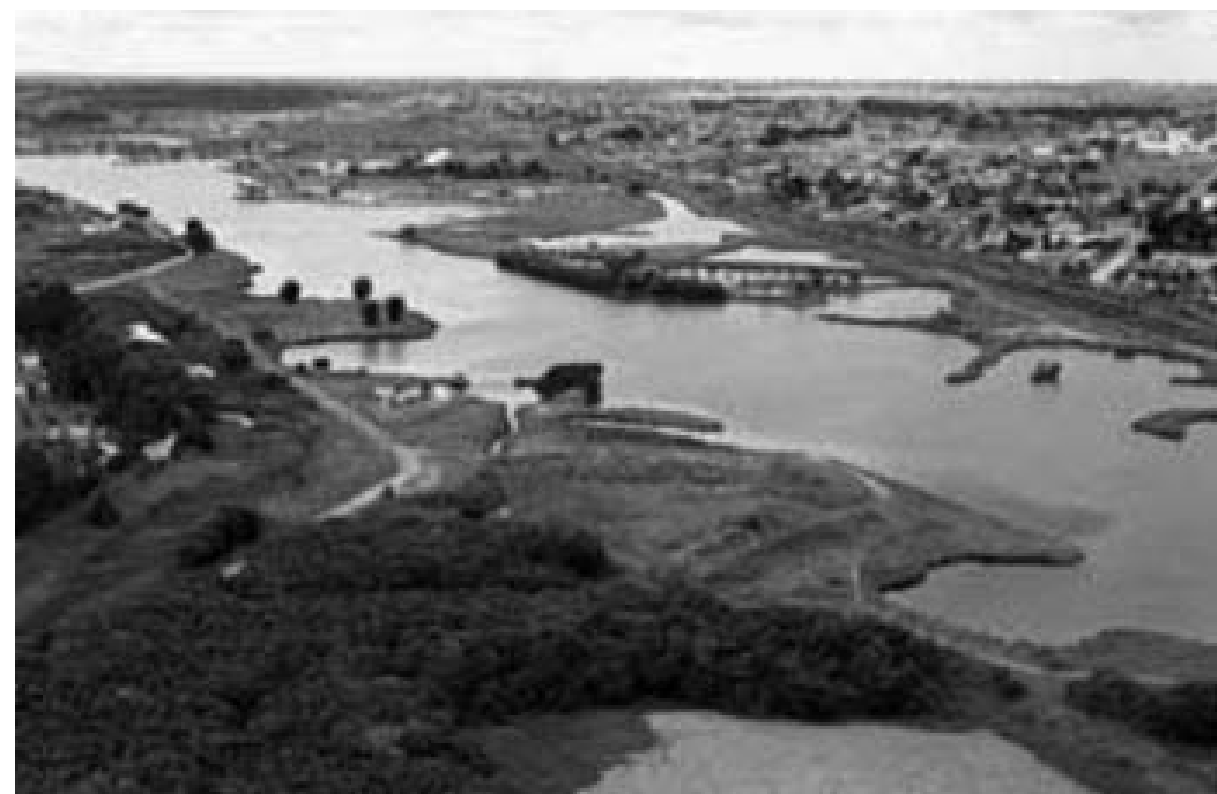

5. PARQUE IGUAÇU

FONTE: PREFEITURA MUNICIPAL DE CURITIBA. Site de Curitiba. <www.curitiba.pr.gov.br> acesso em: 2000. 
com grande vigor, ainda soam no Brasil alternativos, assim como as questões ligadas à revalorização de centros urbanos e históricos. Destacam uma gama de termos, como: renovação, revitalização, reurbanização, refuncionalização, requalificação, reestruturação, reabilitação, restauro, readaptação, para citar os mais freqüentes que estão, via de regra, diretamente ligados a questão da revalorização de centros históricos, um dos carros chefes das experiências urbanísticas no cenário internacional. Nas palavras de Argan (1988, p. 215):

...uma cidade pode ter uma história de décadas, outra de séculos - a história é um fato eminentemente urbano, entre história e cidade há uma relação estreitíssima, tanto assim que cidade e civilização são palavras que têm a mesma raiz. Mas a história é animada dialética, até mesmo luta, de pensamentos e atos, não é a aceleração uniforme de uma função mecânica. Existiram e podem existir cidades históricas de vinte mil almas; existem aldeias industriais de quatro ou cinco milhões de habitantes.

O Projeto de Revitalização do Pelourinho teve como paradigma o processo italiano de intervenção em centros históricos, vinculando-se formalmente a ONGs e organizações de referência, como o Projeto Itália, em Roma. No entanto, o processo de gestão do projeto Pelourinho, nas áreas já recuperadas, colocou-se de forma diversa, com estatísticas de comprovam a opção pelo ressarcimento de 95\% dos inquilinos e sua consequente mudança, realizada em caminhões da prefeitura, para as favelas na periferia de Salvador por escolha própria. Desta forma, como apontam Fernandes e Gomes (1998), a recuperação do centro histórico representou uma operação duvidosa do ponto de vista social e cultural.

Ao mesmo tempo, a discussão do Plano Estratégico para a cidade de Salvador incluiu intervenções de privatização do espaço público para o lazer dirigido e pago dos parques temáticos, como política municipal de concessão de áreas públicas. Água, shopping, alimentação e exotismo produzindo uma alegoria do outro, uma cidade que se transforma em alegoria do visitante, seja ele estrangeiro ou nacional. Áreas de recuperação urbana, como a recente na orla da Barra, produzindo, assim como nas cores do Pelourinho, um cenário ao visitante.

Nas periferias ao norte ou ao sul, como nos históricos alagados de Salvador, a política do saneamento básico em associação com ONGs internacionais e com financia- mento de bancos como BID. A política é tímida com implantação de uma precária rede de esgoto, em áreas invadidas durante décadas, localizadas em cota inferior ao nível do mar. A aproximação com moradores foi feita através de técnicos internacionais vinculados à ONGs, todos de boa vontade, porém cumprindo as determinações dos fundos internacionais de pobreza.

De forma controversa encontra-se a cidade de Curitiba que, sem dúvida, representa uma das cidades brasileiras que mais incorreu em ações planejadas para a redefinição de seu espaço urbano, considerando-se a proposta de Alfred Agache, em 1943, que dentro da concepção modernista dominante da arquitetura, desenha a cidade considerando as áreas definidas por funções afeitas ao período (setores militar, educacional, industrial e de moradias, incluindo as de renda mais baixa) criando uma rede de avenidas de conformação radiocêntrica. Particularmente, é interessante a discussão proposta pelo urbanista francês no que diz respeito ao centro cívico - cuore da cittá - tão pertinente às discussões travadas no contexto do Ciam.

Nos anos sessenta, a cidade de Curitiba conta já com 360.000 habitantes e representa um pólo regional para o Estado, nos moldes das definições de pólos do período. $\mathrm{O}$ processo de Planejamento Urbano, que então se inicia, vai pautar-se na idéia de modernização nos termos do pensamento desenvolvimentista do período, cujo mote passa a ser a industrialização em um contexto estadual rural. Em 1965, o PDU é definido pelo urbanista Jorge Wilheim e Arquitetos Associados, e apoiado por uma equipe local de acompanhamento, com técnicos da prefeitura e professores dos cursos de engenharia e arquitetura da Universidade Federal, embrião do IPPUC - Instituto de Planejamento e Projetos Urbanos de Curitiba, cujo primeiro presidente foi o arquiteto Jaime Lerner.

A partir de 1970, os projetos urbanos elaborados pelo órgão são colocados em prática, sendo que em 1971, o mesmo arquiteto, já então prefeito da cidade, implanta o sistema de circulação e o transportes de massa que redefine os traçados urbanos com suas vias estruturais norte-sul e os corredores de circulação. É desse período a implementação da cidade industrial de Curitiba (1973), o início da construção de grandes parques em um sistema de recuperação das áreas deterioradas das antigas pedreiras e ocupação das áreas vazias e inundáveis da cidade, combinados com um projeto de revitalização do centro urbano nos moldes modernistas. 
VICENTINI, Y. Teorias da cidade e as reformas urbanas contemporâneas

\section{IMAGENS 4 - RIO DE JANEIRO}

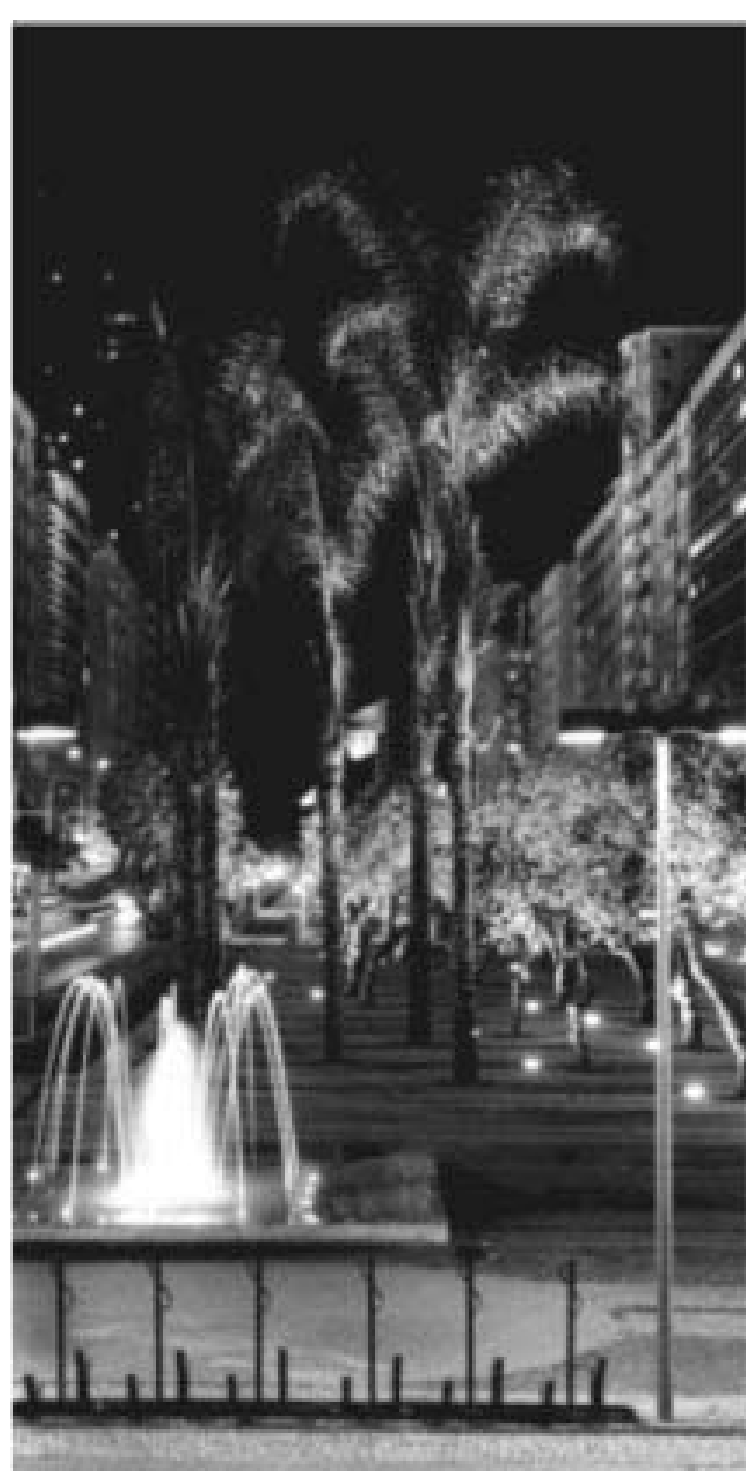

1. CIDADE - COPACABANA
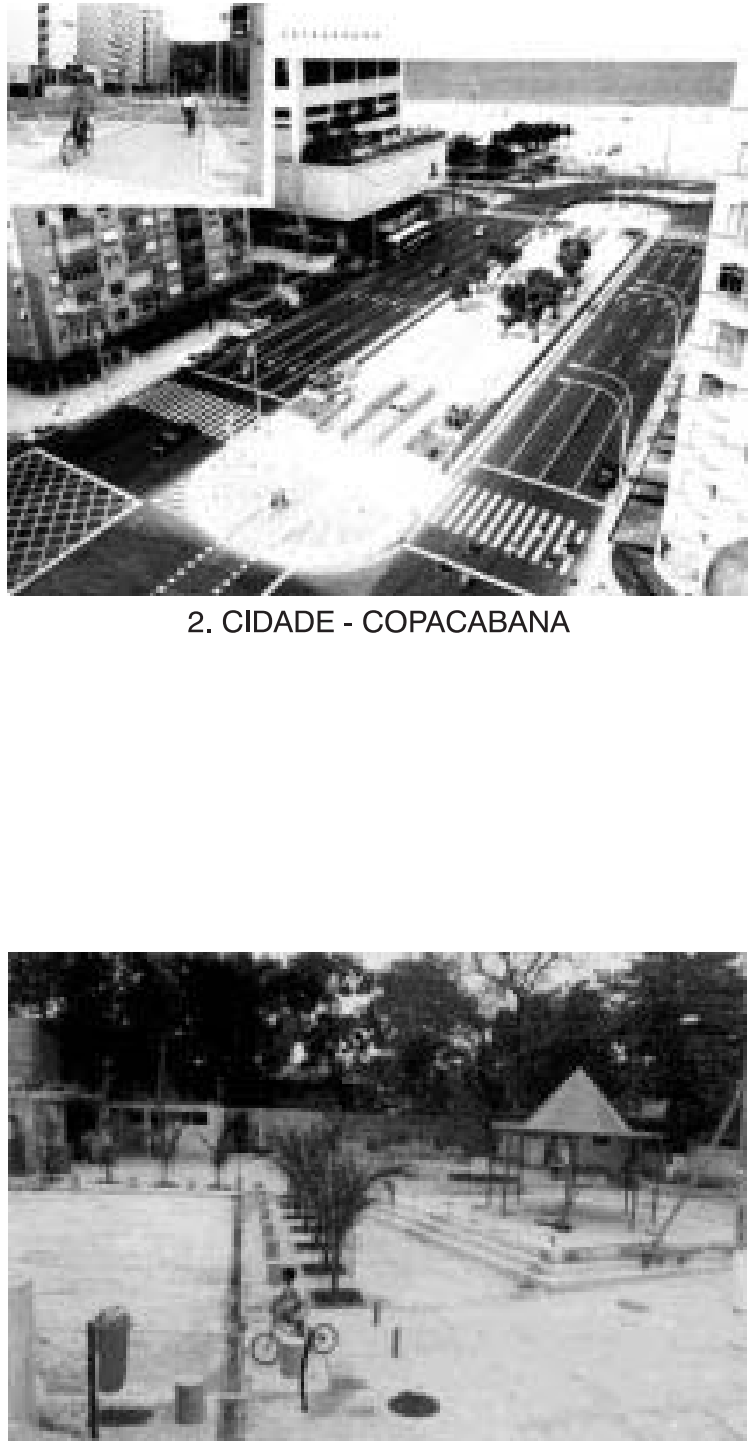

3. FAVELA-BAIRRO - FERNÃO CARDIM

FONTE: RIO DE J ANEIRO. Relatório dos Programas Rio-Cidade, e Favela Bairro do Rio de J aneiro. Rio de J aneiro: Iplan, 1999. 


\section{IMAGENS 4 - RIO DE JANEIRO}
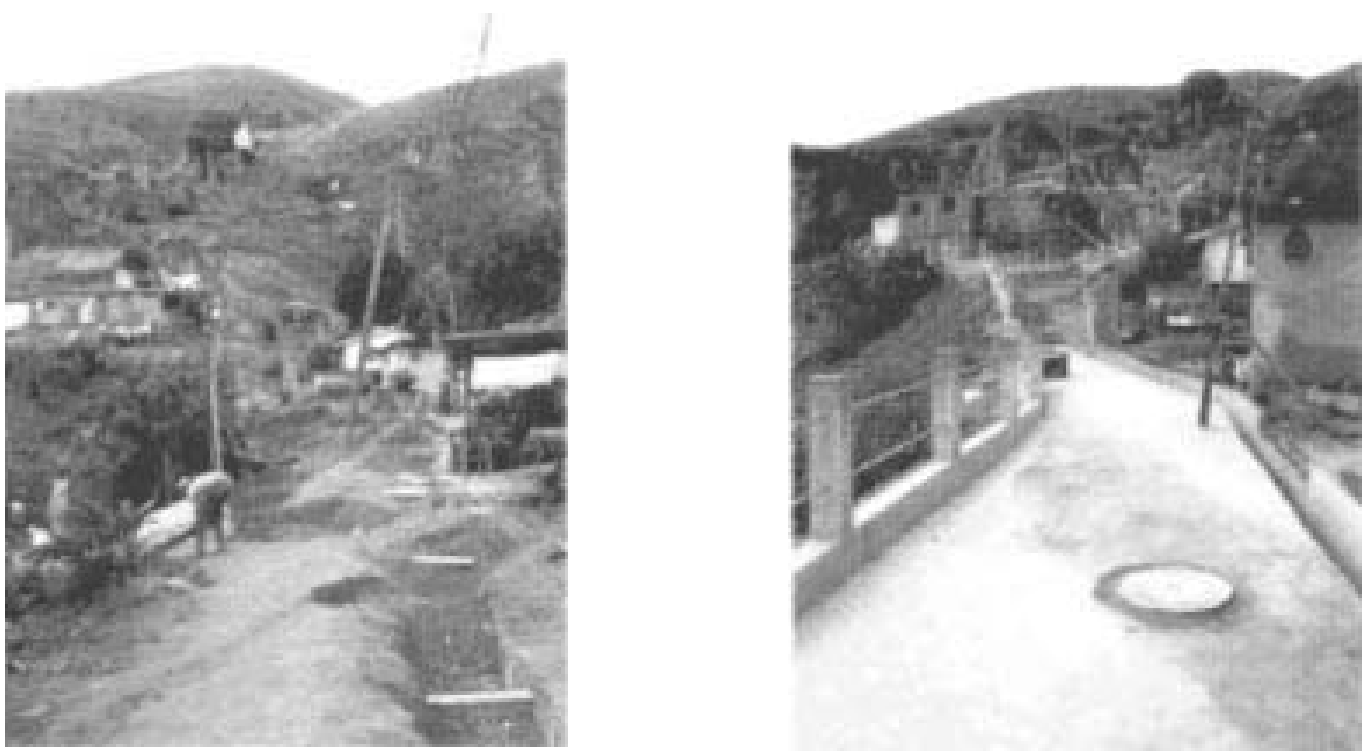

4. FAVELA-BAIRRO - SERRINHA
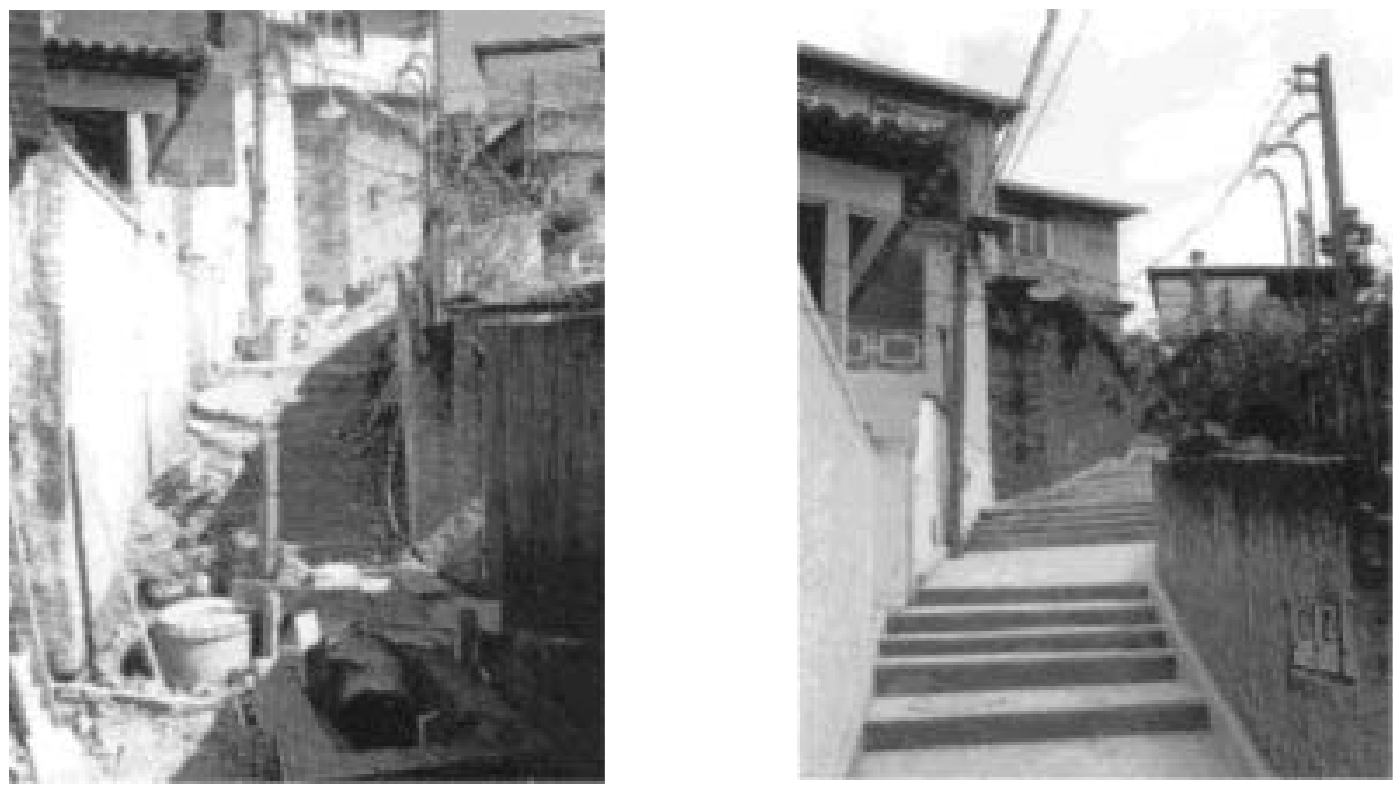

5. FAVELA-BAIRRO - MATA MACHADO

FONTE: RIO DE J ANEIRO. Relatório dos Programas Rio-Cidade, e Favela Bairro do Rio de J aneiro. Rio de J aneiro: Iplan, 1999. 
O conjunto de obras realizadas pelo PDU marcou, inexoravelmente, a Cidade, mesmo com o lapso político partidário subsequente. Ao final da década de 80, a linha mestra de desenvolvimento da cidade é retomada, mesmo que as críticas construídas no período apontassem para a marginalização da população de baixa renda, a maioria habitantes dos municípios vizinhos da região metropolitana. Curitiba passa de um slogan de cidade modelo para o slogan de cidade ecológica, em um alinhamento com as transformações dos discursos sobre o urbano em nível mundial. Uma série de temáticas ambientais e programas específicos são então implementados (parques, memoriais - ver imagens 3) exacerbando uma cultura do consumo da cidade, agora objeto de intensa propaganda que vai, sintomaticamente, incluir a invenção de tradições urbanas através de uma simbologia pensada e de caráter rural - a folha de araucária, o pinhão desenhado nos cruzamentos, a folha da erva mate, os portais de migrantes etc.

Como um exemplo paradigmático, Curitiba assimila o contexto das simulações urbanas culturais das cidades mundiais sem ser, ela mesma, uma cidade mundial ou ecológica, já que todas as suas bacias hidrográficas são poluídas, conforme dados oficiais. Como uma antevisão do contexto contemporâneo das cidades em redes globais, coloca-se na perspectiva imagética dos projetos temáticos urbanos, mantendo seu forte viés rural e conservador.

A cidade, assim pensada, é um fenômeno típico da cultura contemporânea, como uma mediação possível entre as ações políticas, as práticas da comunicação e as intervenções urbanísticas, ou como um simulacro construído.

No entanto, nos anos noventa, as respostas culturais e propagandísticas vêm se esgotando, com a constatação de que Curitiba, com seus lotes urbanos mínimos de 360 $\mathrm{m}^{2}$ e sua legislação urbanística permissiva, possui uma ocupação total da área física do município conurbadas por invasões em áreas de proteção ambiental, ainda que fora dos limites do seu território. O novo recorte ambiental como paradigma do novo pensamento da cidade, por bacias hidrográficas, surpreende um conjunto de 25 municípios que assistem à degradação de seu ambiente, perante as dificuldades de financiamento e novos investimentos urbanos no Brasil neste final de século.

Talvez as análises pertinentes escapem deste texto, quando se referem à manutenção de uma imagem de cidade única e agora isolada de seu contexto regional metropolitano, dadas as dificuldades de assimilar os problemas ambientais e sociais dos quais até agora a cidade manteve- se afastada. Por outro lado, a imagem criada tem que ser mantida mesmo que, para isso, seja necessária, como destaca Silva Bega (1999), a invenção das tradições, quando o antigo núcleo colonial de formação portuguesa, baseado na economia extrativista, foi banido do imaginário coletivo e substituído por uma cidade européia, fruto da mistura de migrantes alemães, italianos, poloneses, ucranianos e russos, conferindo uma identidade branca e européia construída ao largo dos migrantes nacionais, que hoje representam uma população negra e parda de $30 \%$ de seus habitantes.

Finalmente, cabe destacar o processo contemporâneo de pensar a cidade para o Rio de Janeiro. O Rio de Janeiro foi, nesta década, uma das primeiras cidades brasileiras a assimilar os novos paradigmas internacionais de planejamento, tomando emprestado, em particular, a experiência de planejamento estratégico de Barcelona. A par da análise mais detalhada dos projetos urbanos que este pensar a cidade engendrou, é significativa a leitura do Plano Estratégico do Rio de Janeiro em si, uma proposta que se constitui em um novo patamar metodológico da discussão urbana no Brasil.

Nesta perspectiva, vários enfoques podem ser desenvolvidos. Por um lado, a inauguração de um novo ciclo de assimilações do pensamento sobre a cidade no Brasil, inscrevendo a análise no debate das questões que hoje orientam posicionamentos teóricos-analíticos para a compreensão das sociedades contemporâneas, com termos como pósmodernidade, globalização e fragmentação. Por outro lado, implicam em alterações na reestruturação econômica, em reorientações para o planejamento urbano, em novas configurações espaciais e político administrativas, na recomposição técnica do espaço e das formas de ação política e de organização da sociedade.

Nesta direção, o Plano Estratégico para o Rio de Janeiro e suas formulações temáticas sobre a cidade - Rio do ano 2000 - incluíram a expectativa de reverter o quadro de desordem urbana e estabelecer uma nova matriz do poder social na cidade. Pode-se afirmar que, de acordo com as críticas que vem sendo elaboradas como a de Randolph (1996), o Plano contém um modelo de gestão que foi capaz de reinterpretar metodologicamente o modelo Barcelonense, reenquadrando-o aos problemas da cidade, onde se destaca a visão definitiva das favelas urbanas históricas do Rio como bairros, depois de quase um século de repulsa e tentativas de expulsão e a montagem de uma matriz social com parcerias, que consideram as associações de 
classe e representantes do capital empresarial em um consórcio de mais de quarenta empresas.

Em relação ao Programa Favela-Bairro, este se destaca na nova formulação do planejamento na cidade.

O Programa surge inicialmente em 1993, como um dos elementos da Política Habitacional da cidade e, posteriormente, articula-se como Programa que passa a ser incluído no Plano Estratégico da cidade. Resulta de um contrato de empréstimo entre Prefeitura e BID e define componentes diversos como urbanização de favelas, regularização de ocupações em loteamentos, monitoramento e avaliação permanente, educação sanitária e desenvolvimento institucional, conforme explicita Randolph (1996). Pretendia abarcar as favelas urbanas de grande porte, como as visitadas na pesquisa de campo, as favelas da Maré, do Morro do Alemão e Cardim, com mais de 500 domicílios e menos de 2.500 cada, sendo que neste universo o Programa hoje atua em mais de 100 favelas na cidade do Rio de Janeiro, que correspondem a 410.000 habitantes, ou seja, conforme dados projetados do IBGE de 1991, a $43 \%$ do total dos domicílios em favelas do município (ver imagens 4).

É claro que se trata de uma adaptação de um modelo neo-liberal, ou como o define Randolph (1996), um modelo de assimilação de uma nova matriz do poder social para a construção e consolidação de uma hegemonia ideológica amparada em uma retórica social e participativa, com afirmativas próprias de seu principal mentor, Borja (1996). Ou seja, a transferência de modelos centralizadores para a realidade latino-americana inclui problemas adicionais, que vão desde as articulações sociais possíveis, até as dificuldades de transpor o abismo social e de integração e qualidade de vida nas cidades.

Interessante notar que, se o Plano Estratégico do Rio abre um novo período de assimilações para as políticas urbanas no Brasil, ao mesmo tempo não considera as raízes culturais de uma discussão teórico-histórica, onde se concebem os planos estratégicos nas cidades mundiais européias, em particular em Barcelona, matriz deste pensamento.

A dificuldade assinalada é recorrente na compreensão das teorias urbanas contemporâneas frente à formulação de novas políticas e programas urbanos. Se durante todo o século XX no Brasil, os modelos e as teorias urba- nas assimiladas demonstraram sua fragilidade frente a uma análise mais detalhada, expondo dificuldades de concretização do caráter social e político dos mesmos, como já discutiu amplamente Arantes (1998), novamente nos deparamos com tal situação, mesmo que colocada em outros termos.

Enfrentando a dicotomia estabelecida entre um modelo estratégico de planejamento das cidades mundiais, incluindo todos os ingredientes referenciais contemporâneos de volta ao urbanismo do lugar, frente à questão latino-americana das grandes cidades e seus espaços consolidados por décadas de exclusão, a consecução de novos modelos de gestão urbana, em uma nova matriz de acordos sociais, torna inerente mudanças profundas e não previstas nos modelos econômicos em pauta. Longa discussão que se abre para debate.

Acredita-se que, a partir do desenvolvimento teórico-metodológico exposto neste trabalho, pode-se concluir sobre a diversidade das tendências contemporâneas de abordagem das cidades mundiais. Enfatiza-se que estas tendências não são homogêneas ou hegemônicas e decorrem do pensamento pós-guerra sobre as teorias urbanas, no processo de construção da crítica à cidade modernista.

Identifica-se uma linha teórica e metodológica existente em cada uma das correntes analisadas, todas vinculadas a um processo histórico e cultural inerente. Quando reinterpretadas e transpostas, soam como simulacro ou são inviabilizadas por um contexto diverso que, no atual processo de remodelação econômica mundial, exclui parcelas das nações da possibilidade de uma readequação das cidades como um bem estratégico, remodelando este bem para formas de concentração em níveis de consumo mais sofisticados ou de serviços pós-industriais, como fruto de um pensar histórico, cultural e tecnológico.

Nesta medida, aos paradigmas presentes nas grandes reformas urbanas contemporâneas em curso nas cidades mundiais, não correspondem às possibilidades de investimento e renda gerais da população na América Latina, resultando em assimilações incompletas de políticas de gestão urbana ou em cenários mal acabados de projetos urbanos. Em realidade, as grandes cidades brasileiras necessitam de investimentos em infra-estrutura básica e em políticas populares de recuperação da qualidade de vida urbana e de renda. 


\section{REFERENNCIAS}

ARANTES, O. A sobrevida da arquitetura moderna segundo Habermas. Revista AU, n. 30, p. 72-75. Ano 6, jun./ jul. 1990.

O lugar da arquitetura depois dos modernos. São Paulo: Studio Nobel, 1993.

. Urbanismo em fim de linha. São Paulo: Nobel, 1998.

ARGAN, G. C. Historia del arte como historia de la ciudad. Barcelona: Editorial Laia, 1988.

AUGÉ, M. Non- Places : Introduction to an anthropology of Supermodernity. Londres: Verso Editions, 1995.

BEGA, M. T. S. Planejamento - espetáculo e a construção do cidadão consumidor: as imagens de Curitiba. Curitiba: 1997. mimeog.

BUSQUETS, J. La urbanizacion marginal en barcelona. Barcelona: Laboratorio de Urbanismo, Escuela Tecnica Superior de Arquitectura, 1976.

CACCIARI, M.; TAFURI, M.; DAL CO, F. De la Vanguardia a la Metropoli. Barcelona: Editorial Gustavo Gilli, 1979.

CASTELLS, M.; BORJA, J. As cidades como atores políticos. Revista Novos Estudos Cebrap. São Paulo: n. 45, p. 152-166. jul. 1996.

European cities, the informational society, and the global economy. New Left Review. São Paulo: n. 204, p. 18-32. mar./abr. 1994.

La ciudad informacional: tecnologias de la información, reestruturación economica y el proceso urbanoRegional. Madri: Alianza Editorial, 1995.

CLADERA, J. Roca. Rehabilitación urbana. Madri: Ministério de Obras Públicas, 1995.

COLQHOUN, A. Post modern critical athitudes e post modernism and struturalism: a retrospective glanve. In: . Modernity and the classical tradition architectural essays 1980-1987. [S. 1.]: The MIT Press, 1989. p. 235-254. DIEPGEN, E. (Org.). The catalogo e editorial. Berlim: Status, 1998.

FRANÇA, J. A. Lisboa: urbanismo y arquitectura. Lisboa: Horizonte, 1997.
FERNANDES, A; GOMES, M. A. Cidade e urbanismo: história, teorias e práticas MAU/UFBA, 1998.

FERNÁNDEZ, R. Modos de hacer ciudad. Buenos Aires: UBA/ FAUD UNMdP, 1996.

FRAMPTON, K. História crítica de la arquitectura moderna. Barcelona: Editorial GG, 1987.

The isms of contemporary architecture. Revista Modern Architecture and the Critical Present, AD. n. 527/8, p. 60-83, 1982.

GARCIA LAMAS, J. M. R. Morfologia urbana e desenho da cidade. Lisboa: Fundação Calouste Gulbenkean, 1993.

GOTTDIENER, M. A produção social do espaço urbano, Tradução G. G. de Souza. São Paulo: Edusp, 1993.

HABERMAS, J. A arquitetura pós-moderna. Dossiê Habermas. Novos Estudos Cebrap, São Paulo, n. 18, 1987.

O discurso filosófico da modernidade. Lisboa: $\mathrm{Pu}-$ blicações Dom Quixote, 1990.

HARVEY, David. Condição pós-moderna. São Paulo: Loyola, 1992.

IBA - INTERNATIONALE BAUAUSS TELLUNG BERLIN. Project report, senator for building and housing. Berlin: [s. n.], 1990.

JACOB, J. The failure of town planning. USA: Pelican Book, 1964.

JAMESON, F. Pós-modernidade e sociedade de consumo. Revista Novos Estudos Cebrap, São Paulo, n. 12, 1984.

LEFEBVRE, H. O pensamento marxista e a cidade. Lisboa: Editora Ulisséia, 1972.

MARICATO, E. Metrópole na periferia do capitalismo. São Paulo: Hucitec, 1996.

MONTANER, J. M. Después del movimiento moderno arquitectura de la segunda mitad del sigli XX. Barcelona: Editorial GG, 1993.

NOVAES, A. (Org.). A invenção do novo, em tempo e história. São Paulo: Secretaria de Cultura/Companhia das Letras, 1992.

PREFEITURA MUNICIPAL DE CURITIBA. Site de Curitiba. Disponível em: 〈http://www.curitiba.pr.gov.pr> Acesso em: 2001. 
VICENTINI, Y. Teorias da cidade e as reformas urbanas contemporâneas

RANDOLPH, R. Determinações estratégicas e potencialidades de transformação do programa favela-bairro. Rio de Janeiro: Ippur, 1996.

RIO DE JANEIRO. Relatório dos programas Rio-cidade e favela-bairro. Rio de Janeiro: Iplan, 1999.

SANTOS, B. Introdução a uma ciência pós-moderna. Rio de Janeiro: Graal, 1989.

Pela mão de Alice - o social e o político na pósmodernidade. São Paulo: Cortez, 1995.
TAFURI, M. Projecto e utopia . Lisboa: Presença, 1985.(Coleção Dimensões).

VATTIMO, G. El fin de la modernidad. Barcelona: Gedisa Editorial, 1985.

GUERRA, M. La rénovation urbaine à berlin depuis 1989: la grande transformation, La recherche sur la Ville en Alemagne. Programme Interdisciplinar de Recherche sur la Ville. Paris: CNRS Éditions, 1996. 